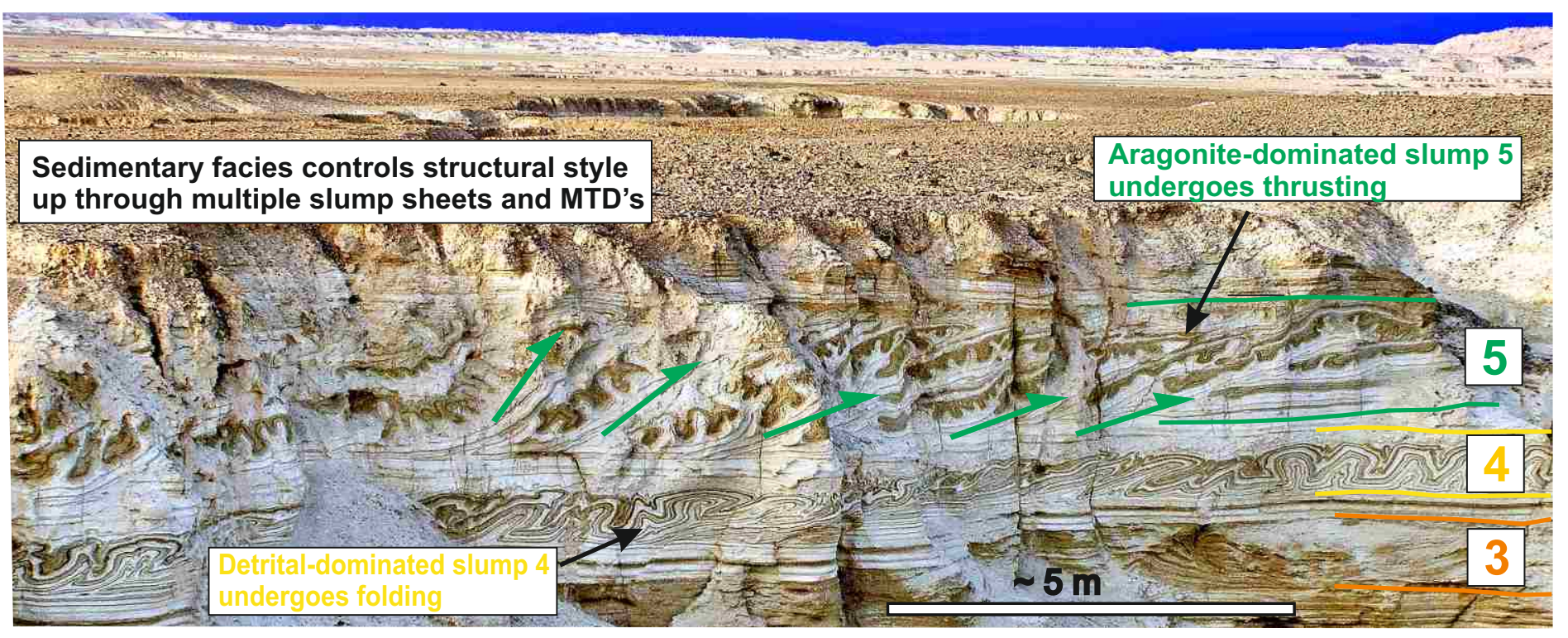




\section{Sedimentary and structural controls on seismogenic slumping within Mass Transport Deposits from the Dead Sea Basin G.I. Alsop ${ }^{1}$, S. Marco ${ }^{2}$, R. Weinberger ${ }^{3,4}$, T. Levi ${ }^{3}$.}

1) Department of Geology and Petroleum Geology, School of Geosciences, University of Aberdeen, Aberdeen, UK. (e-mail: Ian.Alsop@abdn.ac.uk) 2) Department of Geosciences, Tel Aviv University, Israel. 3) Geological survey of Israel, Jerusalem, Israel.

4) Department of Geological and Environmental Sciences, Ben Gurion University of the Negev, Beer Sheva, Israel.

\section{Abstract}

Comparatively little work has been undertaken on how sedimentary environments and facies changes can influence detailed structural development in slump sheets associated with Mass Transport Deposits (MTD's). The nature of downslope deformation at the leading edge of MTD's is currently debated in terms of frontally emergent, frontally confined and open-toed models. An opportunity to study and address these issues occurs within the Dead Sea Basin, where six individual slump sheets (S1-S6) form MTD's in the Late Pleistocene Lisan Formation. All six slumps, which are separated from one another by undeformed beds, are traced towards the NE for up to $1 \mathrm{~km}$, and each shows a change in sedimentary facies from detrital-rich in the SW, to more aragonite-rich in the NE. The detrital-rich facies is sourced predominantly from the rift margin $1.5 \mathrm{~km}$ further $\mathrm{SW}$, while the aragonite-rich facies represents evaporitic precipitation in the hyper saline Lake Lisan. The stacked system of MTD's translates downslope towards the NE, and follows a pre-determined sequence controlled by the sedimentary facies. Each individual slump roots downwards into underlying detrital-rich layers and displays a greater detrital content towards the SW, which is marked by increasing folding, while increasing aragonite content towards the NE is associated with more discrete thrusts. The MTD's thin downslope toward the NE, until they pass laterally into undeformed beds at the toe. The amount of contraction also reduces downslope from a maximum of $\sim 50 \%$ to $<10 \%$ at the toe, where upright folds form diffuse 'open toed' systems. We suggest that MTD's are triggered by seismic events, facilitated by detrital-rich horizons, and controlled by palaeoslope orientation. The frequency of individual failures is partially controlled by local environmental influences linked to detrital input, and should therefore be used with some caution in more general palaeoseismic studies. We demonstrate that MTD's display 'open toes' where distributed contraction results in upright folding and shortening rather than distinct thrusts. Such geometries may account for some of the contraction that is apparently missing when balancing seismic sections across large off shore MTD's.

Keywords: slump, MTD, seismites, soft sediment deformation, Dead Sea Basin

\section{Introduction}

The study of mass transport deposits (MTD's) has been facilitated by improved seismic resolution, and has shown on a large scale that sedimentation can influence where subsequent slope failure occurs (e.g. Rowan et al., 2004; Morley et al., 2011; Peel, 2014; Armandita et al., 2015). However, traditional models of slumping generated on a small scale typically tend to assume a layer-cake stratigraphic template, although more recent works suggest that slumps may be generated due to slope instabilities associated with rapid sedimentation and associated facies changes (e.g. Odonne et al., 2011). The coarse grain size and thick beds in 
such settings are not conducive to structural analysis as they typically lack the refined stratigraphy and precise markers necessary for detailed correlation of structures within individual slump sheets. Despite the differences in scale, the outcrop study of well exposed slump systems is important as it provides further details and constraints on large scale MTD's that are imaged seismically offshore (e.g. Worrall and Snelson,1989; Morley and Guerin, 1996; Frey-Martinez et al., 2005; Bull et al., 2009; Morley et al., 2011; Jackson, 2011).

Traditional models of slumping associated with MTD's assume that the amount of extension in the upslope 'head' region of a slumped mass should be balanced by the amount of contraction in the downslope 'toe' within the same sheet (Farrell, 1984, see also Alsop and Marco, 2014) (Fig. 1a). However, such equilibria are in reality rarely observed, with significant amounts of contraction required to balance large-scale slumps or MTD's missing from seismic sections (e.g. Butler and Paton, 2010; de Vera et al., 2010). Such disparities could be attributed to out of section movement during gravity spreading (see discussion in Alsop and Marco, 2011), or lateral compaction of sediments at the leading edge of MTD's that may create structures and fabrics that are below the resolution of the seismic imaging (e.g. Butler and Paton, 2010; de Vera et al. 2010).

The main aims of this work are therefore to discuss a) the stratigraphic and sedimentological influences that collectively form environmental controls on styles of deformation in slump sheets, and $b$ ) the nature of deformation at the leading downslope toes of slump sheets. This paper addresses a number of basic questions relating to these aims including:

i) Does the amount of slump sheet translation sequentially vary up through a sequence?

ii) Do slumps reworked by multiple seismic events display different amounts of translation?

iii) Do slumps maintain a constant flow direction up through a sequence of several slumps?

iv) Does the thickness and spacing between individual slump sheets vary downslope?

v) How does the thickness and extent of sediment caps vary above slump sheets?

vi) Does the amount of contraction vary towards the downslope toe of each slump?

vii) What structures mark the leading edge of slump sheets?

viii) Does lithological variation control structural style within slump sheets?

ix) What factors control the timing and frequency of slumps?

The Late Pleistocene Lisan Formation outcropping on the western margin of the Dead Sea Basin is an ideal place to study these issues as individual slumps are superbly exposed allowing them to be easily correlated and traced. The recent investigation of drill cores taken from the depocentre of the Dead Sea reveals that the stratigraphic thickness of the Lisan Formation is three times greater than its onshore equivalent, largely due to the input of transported sediment and disturbed layers (Marco and Kagan, 2014). The slump systems observed onshore ultimately may form part of these larger MTD's that feed into the deep basin. The quality of onshore outcrop is perhaps unparalleled and this permits greater detailed analysis of MTD slump systems than otherwise possible. In addition, lateral facies changes are observed within slumps making them an especially good analogue for larger-scale marine MTD's which frequently are associated with variable sedimentary input (e.g. Peel, 2014). 


\section{General slump patterns}

Gravity-driven slumps of poorly lithified or 'soft-sediments' (e.g. Maltman, 1984) deform by particulate flow (e.g. Knipe, 1986), with the ratio of pore fluid pressure and cohesive strength of the sediment (due to grain weight) controlling the nature of the resulting structures (e.g. Knipe, 1986; Ortner, 2007). If pore fluid pressure is equal to, or greater than, the cohesive strength of the sediment, then bedding is effectively destroyed as the sediment either liquefies or fluidises, respectively. However, where pore fluid pressure is marginally less than the cohesive strength of the sediment, it deforms by hydroplastic deformation, which preserves primary features such as bedding, and this enables slump folds and shears to be defined. An increase in pore fluid pressure therefore provides an effective mechanism by which to reduce the shear strength of sediments, and generate gravity-driven slope failure (e.g. Maltman, 1994a, b, c, d and references therein). Pore fluid pressures may be dramatically increased by a variety of processes including rapid deposition, and passage of earthquake-induced seismic waves through the soft sediment. It may also be elevated by the downslope translation of a slumped mass that increases the loading on the underlying sediments and facilitates further movement and deformation (e.g. Strachan, 2002).

The geometry and kinematics of gravity-driven slumps of unconsolidated MTD sediment have previously been modelled in terms of deformation cells translating downslope, that are marked by extension in the upslope or 'head' portion of the slump that is broadly balanced by contraction in the downslope or 'toe' area of the slump (e.g. Hansen, 1971; Lewis, 1971; Farrell, 1984; Farrell and Eaton, 1987; Elliot and Williams, 1988; Martinsen, 1989, 1994; Martinsen and Bakken, 1990; Smith, 2000; Strachan, 2002, 2008; Gibert et al., 2005) (Fig. 1a, b). Within such models, translation of the slump sheet occurs along an underlying detachment or failure surface, with extension at the head accommodated by normal faults and fractures, while folds are generated by contraction in the lower portion of the slump (Fig. 1a, b). The lateral margins of the slumped mass are interpreted to be zones of differential or layer-normal shear that are broadly parallel to general downslope-directed movement (e.g. Farrell, 1984; Debacker et al., 2009; Sharman et al., 2015) (Fig. 1a, b). These overall patterns on the scale of the slump may be repeated at smaller scales when transient $2^{\text {nd }}$ order flow cells develop during translation of the slumped mass (Alsop and Marco, 2014).

In a simple traditional model, displacement is broadly uniform along the strike of the palaeoslope resulting in layer-parallel shearing, whereby the hinges of slump folds are orientated normal to the slope direction, axial planes dip in the upslope direction, and the overall slump fold system verges downslope (e.g. Woodcock, 1976a, b, 1979; see Alsop and Holdsworth, 2007) (Fig. 1a, b). Fold facing, which is defined as the direction normal to the fold hinge in which younger beds are encountered along the axial plane (e.g. Holdsworth, 1988), is typically upwards and towards the downslope direction (Fig. 1a, b). This model starts to break down with increasing deformation associated with translation of the slump, when fold hinges may rotate towards the downslope direction to create curvilinear sheath folds associated with shear zone-like behaviour (Strachan and Alsop, 2006; Ortner, 2007; 
Differential shear above the lateral tips to elliptical basal detachments of slump sheets (Fig. 1a, b) may also encourage folds to initiate at variable angles to the slope direction, leading to distinct relationships between fold hinge and axial plane orientation, vergence, and the downslope direction (see Alsop and Holdsworth, 1993; 2007; Debacker et al., 2009, Alsop and Marco, 2012a, Sharman et al., 2015). The resulting complexity created from folds initiating at variable orientations, or undergoing variable amounts of rotation downslope may be viewed as part of a single progressive deformation during continued translation of the slump sheet (Alsop and Holdsworth, 2007).

\section{Regional geology}

The Dead Sea Basin is a pull-apart basin developed between two parallel fault strands that define the Dead Sea Fault system (Garfunkel, 1981; Garfunkel and Ben-Avraham, 1996) (Fig. 2a, b). This plate-boundary transform between the Arabian and African (Sinai) plates has been active since the Miocene (e.g. Bartov et al., 1980; Garfunkel, 1981) including during deposition of the Lisan Formation in the Late Pleistocene (70-15 ka) (Haase-Schramm et al., 2004) (Fig. 2b). The Lisan Formation comprises a sequence of alternating aragonite and detrital-rich laminae, which define couplets on a sub-mm scale. They are considered to represent annual varve-like cycles with aragonite laminae precipitating from hypersaline waters in the hot dry summer, while winter floods wash clastic material into the lake to form the detrital-rich laminae (Begin et al., 1974). Varve counting combined with isotopic dating suggests that the average sedimentation rate of the Lisan Formation is $\sim 1 \mathrm{~mm}$ per year (Prasad et al., 2009). Seismic events along the Dead Sea Fault, rather than rapid sedimentation, are considered to trigger surficial slumps within the Lisan Formation, resulting in well-developed seismites (e.g. Agnon et al., 2006) which include soft-sediment fold and thrust systems about $1.5 \mathrm{~m}$ thick (e.g. El-Isa and Mustafa, 1986; Alsop and Marco, 2011).

The slumps, together with the intervening undeformed beds within the Lisan Formation, are themselves cut by vertical sedimentary injections containing fluidised sediment sourced from underlying units (e.g. Marco et al., 2002; Levi et al., 2006, 2008). Within the sedimentary injections, optically stimulated luminescence (OSL) ages of quartz give ages of between 15 and $7 \mathrm{ka}$, indicating intrusion after deposition of the Lisan Formation (Porat et al., 2007). Slump systems associated with MTD's around the Dead Sea Basin are developed on very gentle slopes of $<1^{\circ}$ dip and define an overall pattern of radial slumping directed towards the depo-centre of present Dead Sea Basin (Alsop and Marco, 2012a, 2013) (Fig. 2c).

\section{Overall patterns of slumping at Peratzim}

The Peratzim study area $\left(\mathrm{N} 31^{\circ} 0449.6\right.$, E $\left.35^{\circ} 2104.2\right)$ on the western margin of the Dead Sea Basin is about $1.5 \mathrm{~km} \mathrm{NE}$ of the normal-oblique basin-bounding faults that juxtapose Cretaceous carbonates with the Late Pleistocene Lisan Formation (Fig. 2c, d). During storm events, canyons within the uplifted Cretaceous margin periodically undergo flash floods that introduce detritals into the basin. The Peratzim area is close to the entrance of one such major canyon named Wadi Ami'az (Fig. 2d), which is directly linked to input of 
detritals into the basin and the Lisan Formation. Immediately to the east of where Wadi Ami'az enters the basin, well-developed metre-scale extensional faults are formed in coarse, detrital-rich Lisan Formation (Fig. 3a-f). Based on field observations in this proximal fan setting, the Lisan Formation comprises coarse conglomerates, sandstones and detrital muds. The conglomerates and sandstones display metre-scale cross bedding with foresets indicating that the detrital fan was deposited from currents flowing towards the NE away from the wadi (Fig. 3a, b, c). These lithologies thicken in the hangingwall of pronounced listric growth faults that detach into conglomerate and mud-rich horizons (Fig. 3 a-f). Small antithetic normal faults are developed to accommodate the rotational component of slip that generates rollover anticlines, in the hangingwall of listric faults (Fig. 3d) (e.g. Cosgrove, 2015). Extension is directed down the regional palaeoslope towards the NE (Fig. $3 \mathrm{~d}$, e, f), but also towards the SW and the basin margin (Fig. 3 a, b, c). Reversals in the direction of regional and counter-regional extension may relate to local bathymetric relief associated with sediment influx from the Wadi Ami'az fan, or to back tilting of large-scale fault blocks along the western margin of the Dead Sea Fault system.

Continuous across strike exposure at Wadi Peratzim enables the rapid lateral facies variations associated with input of detrital-rich horizons into the aragonite-rich Lisan Formation to be observed. Detrital units within the Lisan Formation largely comprise clays, silts, and fine sands, although as noted above, coarser horizons incorporating sands and gravels are locally preserved towards Wadi Ami'az. Thicker $(>10 \mathrm{~cm})$ detrital units are generally coarser (fine sand), and in some instances display reverse grading of aragonite clasts, with larger (up to $5 \mathrm{~cm}$ ) fragments preserved towards the top of the bed.

Compositionally, the detrital units have been sampled $<1 \mathrm{~km} \mathrm{NE}$ of the present study by Haliva-Cohen et al. (2012), and are found to mainly consist of quartz and calcite grains with minor feldspar, and clays (illite-smectite). Detrital laminae within the varved aragonite-rich Lisan Formation display grain sizes of $\sim 8-10 \mu \mathrm{m}$ (silt), while the thicker detrital-rich units are generally coarser grained $(60-70 \mu \mathrm{m})$ and can be classified as very fine sands (HalivaCohen et al., 2012). This study now focuses on the overall geometries and detailed structures preserved within the downslope toes of the slumps at Peratzim (Fig. 2d).

\subsection{Extent of individual slump sheets}

Six individual slump sheets (S1-S6) are mapped in the canyons that form the Wadi Peratzim area (Figs. 2d, 4, 5a-i). The observed upslope (SW) extent of each slump horizon is constrained by the present erosion level at the base of the modern wadi, and extensional structures at the head of the slump are not typically observed. However, slump toes are significant as deformed horizons can be directly traced laterally towards the NE into undeformed beds (Fig. 5a, b, c). Following previous studies, all slumps are considered as surficial and to be developed on the lake floor, as a) the upper parts of each slump are truncated and eroded, b) immediately overlying beds that cap the slump display grading of aragonite fragments that infill local slump-related topography, c) undeformed beds overlying slumps thicken and thin for up to $0.5 \mathrm{~m}$ above slump topography (e.g. see Alsop and Marco, 2011, 2012a, b, 2013, 2014 for further details). 
In general, all six slump sheets display a greater detrital component when traced upslope towards the SW and the Cretaceous margin. As noted previously, detrital units are primarily formed of grains of quartz, calcite and feldspars, and comprise muds, silts, and fine sand grade material, together with subordinate conglomerates (Fig. 3a-f). Detrital units typically become thicker and coarser towards the SW, while the proportion of aragonite-rich units progressively diminishes. The distance that detrital-rich units extend towards the NE into the aragonite-rich basinal facies progressively reduces up through the slump sequence, such that slump sheets 4, 5 and 6 display less detrital input downslope (Fig. 5d, e, f), while slumps 1, 2 and 3 are marked by detrital-rich horizons extending furthest downslope (Fig. $5 \mathrm{~g}$, $\mathrm{h}, \mathrm{i})$. Thus, each slump sheet displays a similar lateral facies transition from detrital-rich to aragonite-rich as it is traced downslope, although the positon of this transition generally recedes upslope with each successive slump event.

Slump 1 is the oldest slump horizon and is mapped furthest to the NE at $2000 \mathrm{~m}$ from the basin-bounding faults, before passing laterally into undeformed beds (Table 1). The downslope limits of overlying slump sheets systematically extend less far to the NE, as each slump recedes upslope (Fig. 4, Table 1). Thus, each successively younger slump displays less downslope translation towards the NE, and this broadly corresponds with a reducing detrital input up though the slump sequence.

\subsection{Variation in fold orientations within adjacent slump sheets}

Slump folds are considered to be created by hydroplastic deformation (see Alsop and Marco, 2013, p52) and have been analysed in terms of orientation of fold hinges, fold vergence, attitudes of axial planes and direction of fold facing. A general analysis of folding in slumps in the Peratzim area by Alsop and Marco (2012a) indicated an overall N to NE direction of transport. In this more detailed study, slumps 1, 2 and 3 typically display ENE to ESE trending fold hinges (Fig. 6a, b, c), while slumps 4, 5, and 6 are marked by SE to S orientated hinges (Fig. 6d, e, f, Table 1). The associated axial planes typically dip gently towards the South, and display concomitant ENE to ESE strikes in slumps 1, 2, 3 (Fig. 6a, b, c), and ESE to SE trends in slumps 4, 5, and 6 (Fig. 6d, e, f). Fold facing is directed up towards the NNW and NNE in slumps 1, 2 and 3, and up towards the NE and ENE in slumps 4, 5 and 6 (Fig. 6a$\mathrm{f}$, Table 1). Combining fold hinge and axial plane orientations, together with fold facing directions gives calculated slump transport directions (TD) using the mean axis method (MAM), mean axial planar strike method (MAPS), fold trends associated with steeper $\left(>30^{\circ}\right)$ axial planar dips, and mean direction of fold facing (see Alsop and Marco, 2012a for details of methodology) (Fig. 6 a-f, Table 1). In summary, the lower slumps 1, 2, 3 indicate mean transport directions toward $020^{\circ}, 002^{\circ}$, and $028^{\circ}$ (mean $026^{\circ}$ ) respectively, while the upper slumps 4,5 , and 6 are directed towards $046^{\circ} 044^{\circ}$ and $065^{\circ}$ (mean 052 $2^{\circ}$ (Fig. 6 a-f, Table 1).

\subsection{Thickness and spacing of individual slump sheets}

The orthogonal thickness of individual slump horizons 1 to 6 was systematically recorded at different sites along the canyon walls, and generally increases with distance measured upslope from the toe of each slump (Fig 7a). The maximum thickness of the slumps is $2.40 \mathrm{~m}$ 
(Table 1), and each slump may be traced upslope from the toe for a maximum of $500 \mathrm{~m}$ until it is below the level of current wadi incision and no longer exposed. The thickness of each slump at the toe does not reduce to zero due to the thickness of the pre-existing depositional sediment package that is being deformed.

The thickness of each slump may be compared with the distance measured upslope from the toe, where values are normalised against maximum thickness and maximum distance that an individual slump can be traced (Fig 7b). The graph shows that the overall trends flatten towards the origin, reflecting the thickness of the undeformed sediment package next to the toe (Fig 7b). The graph highlights that this flattening is developed at 0.25 of the total distance that the slump is traced for, and occurs at 0.25 of the maximum thickness i.e. most slumps undergo a maximum $\mathrm{x} 4$ thickening compared to the downslope undeformed sediment thickness. The similarity of trends suggests that each slump is exposed for a similar proportion of their overall extent (reflecting similar dips of slump sheets and similar gradients of modern wadi incision to expose the slumps).

The thickness of each slump sheet is compared with the downslope limit of each slump (referenced against the toe of slump 1 that extends furthest downslope towards the NE) (Fig 7c). Each successive slump terminates further upslope resulting in the overall system being exposed for $\sim 800 \mathrm{~m}$ across strike. Slump 3 shows less upslope thickening, possibly reflecting its greater detrital component. Slump 5 extends further downslope than either the immediately underlying or overlying slump, and may reflect reworking and reactivation of this slump by a double seismic event (see Alsop and Marco, 2011).

The thickness of individual slump horizons was measured, and compared with the thickness of undeformed beds that define the spacing to the underlying slump horizon (Fig 7d). In general, as the thickness of each slump sheet increases, then the spacing to the top of the underlying slump decreases. The spacing between a slump horizon and the underlying slump therefore typically increases as the slump is traced downslope. The overall effect of this is for a smaller proportion of the overall sequence to contain slump sheets in the downslope section (i.e. slumps in the upslope area are typically thicker and more closely spaced to one another, meaning that an overall greater proportion of the sequence contains slumps). Whilst the spacing of slump 1 cannot be calculated (as there is no underlying slump to measure to), it is apparent that the lower slumps (S2, S3) are more widely spaced (although no thicker) than the upper slumps (S4, S5, S6). Assuming constant rates of deposition in the Lisan Formation, this suggests that the frequency of slumping varied or reduced through the sequence.

\subsection{Thickness and extent of sediment caps above slump sheets}

Slump sheets are directly overlain by a thin, sometimes graded, sediment layer that is interpreted to have been formed of sediment deposited out of suspension from turbid flows marking seiche and tsunami events (e.g. Alsop and Marco, 2012b). These sediment caps locally thicken to infill underlying slump topography, and display erosive lower contacts where underlying slump structures are truncated by turbulent water flow (Alsop and Marco, 2012b). The maximum thickness of the sediment cap increases with distance measured 
upslope from the toe of each slump (Fig. 7e). The maximum thickness of the cap is $213 \mathrm{~mm}$ (Slump 1), and in general the thickness of measured sediment caps reduces up through the sequence, with slumps 1 and 2 having the thickest caps and slumps 3 and 4 having the thinnest caps (Table 1).

The thickness of the sediment cap increases with the recorded thickness of each slump (Fig. 7f). The correlation between slump thickness and cap thickness suggests that at least some of the sediment deposited from suspension to create the cap is locally derived. This is supported by the preservation of delicate folded aragonite fragments within caps (e.g. Alsop and Marco, 2012b, fig. 7d). For any given thickness of slump, slumps 1 and 2 tend to have thicker caps when compared to the younger slumps. Sediment caps are observed to continue beyond the downslope termination of slump sheets, suggesting that the turbid flow from which sediment was deposited also extended over a larger area.

\subsection{Variation in downslope contraction within slump sheets}

The $\%$ contraction within a slump sheet may be estimated by measuring the shortening across folds and thrusts (e.g. see Fossen, 2010 p. 227). Note that this does not take account of discrete shear fabrics that do not offset bedding, and therefore represents a minimum. The $\%$ contraction in each slump is lowest at the toe (10-20\%), and progressively increases upslope to $\sim 50 \%$ (Fig. $7 \mathrm{~g}$ ). As the toe of each successive slump typically recedes upslope, then each overlying slump will contain less contraction than shown in the slump exposed immediately beneath it. Note that slump 3 does not display a distinct trend as it comprises a thicker detrital unit that does not readily preserve fold or thrust geometries (Fig. 5g). The \% contraction within each slump horizon is also compared with the normalised distance from the toe of each slump, and once again shows a pronounced upslope increase from $<10 \%$ near the toe to $50 \%$ in upslope portions (Fig. $7 \mathrm{~h}$ ).

\section{Detailed structures within slump sheets}

There are numerous extensional and contractional features developed that are considered to relate to $2^{\text {nd }}$ order flow cells within the downslope toes of slumps (see Alsop and Marco, 2014). Only those pertinent to the present work are described below.

\subsection{Extensional structures}

Extension at the toes of slumps is manifested by normal faults that developed during and immediately after each slump event (e.g. Alsop and Marco, 2011, 2014). In addition to the normal faulting noted above, extension may also be accommodated by attenuation and thinning of beds (Fig 8a, b). Folding at the leading edge of m-scale flow cells leads to thickening, while thinning at the trailing edge is marked by extreme attenuation of layering rather than normal faulting (Fig 8a). It is likely that attenuation of beds may accommodate a significant component of extension within slump sheets, especially within detrital-rich horizons. 


\subsection{Contractional structures}

Thick detrital-rich layers are typically dominated by folding, and appear more incoherent than aragonite-rich facies that contain thrusts and form systematic structures (see Alsop and Marco, 2013). Larger folds within aragonite-rich units typically detach onto detrital-rich horizons, which act as either basal or internal detachments within the slumped unit (Fig. 8c). Some folds within detrital-rich units were exposed at the sediment surface as they are directly overlain by the sediment cap deposited from suspension (Fig. 8d). These observations suggest that some of the thick detrital-rich layers were weak (see Alsop and Marco, 2011, 2013), possibly as a result of water trapped in them during rapid deposition by input from wadi floods.

Well defined, upright, open to tight folds are developed at the toes of a number of slumps including slump 4 (Fig. 8e) and slump 3, which is easily traced as it is positioned between two thin detrital-rich markers that act as 'tramlines' for the slump (Figs. 5i, 8f). Although these folds display only weak downslope vergence, underlying layers still display minor thrusts, indicating that there was a component of downslope contraction in the folds rather than being driven entirely by reversed density gradients and overturn in the layers (Fig. 8g) (see Alsop and Marco, 2011). This zone of upright folding may be followed for $\sim 100 \mathrm{~m}$ at the toe of slump 3 until it eventually dissipates downslope into undeformed beds (Fig. $8 \mathrm{~h}$ ). No major thrusts are present at the downslope toe of this slump system.

\section{Reactivation and reworking in slump sheets}

While the precise duration of individual slump events remains uncertain, the observation that they are capped by sediment interpreted to be deposited out of suspension from the associated seiche or tsunami wave (Alsop and Marco, 2012b) suggests they may form in a matter of just hours or days. Structures generated during slumping may be reactivated in the latter phases of the same slump event, or alternatively may be reworked during an entirely later episode.

\subsection{Reactivation during the same slump event}

Some faults have acted as contractional thrusts during initial slumping and have developed hangingwall anticlines associated with downslope movement (Fig. 9a, b, c). However, further up the same fault plane, a normal sense of drag is preserved in the footwall and hangingwall of the fault (Fig. 9a, b). In addition, the sedimentary cap above the slump displays dramatic thickening and growth into the hangingwall of the fault, confirming that the fault was behaving with a normal sense of movement (Fig. 9b). Thus, faults which initiated as thrusts during slumping are subsequently reactivated as normal faults during deposition of the immediately overlying cap (Fig 9, a, b, c). Similar extensional reactivation of gravity-driven thrust complexes in MTD's has recently been suggested by Armandita et al. (2015). Inversion of fault movement during a single slump event highlights the complex kinematics and the potential for reactivation and re-use of structures.

\subsection{Reworking of slumps by later events}


It has previously been noted that the sedimentary caps of some slumps are themselves reworked by later thrusts, suggesting that slump horizons may conceal more than one contractional slump event (e.g. slump 5, Fig 9d) (Alsop and Marco, 2011). A consequence of this is that seismicity that triggers slumps may also occur more frequently and have shorter recurrence intervals than that calculated by simply counting the number of slumps in a sequence (see Alsop and Marco, 2011).

In a particularly clear example of slump reworking, a thrust rooted within a slump cuts the overlying sedimentary cap together with an additional $0.85 \mathrm{~m}$ (Fig. 9e, f) and $0.5 \mathrm{~m}$ (Fig. 9g) of overlying aragonite-rich stratigraphy. Assuming a sedimentation rate of $\sim 1 \mathrm{~mm}$ per year (Prasad et al., 2009), then later thrusting took place about 850 years and 500 years after the initial slump event in each case. This significant gap in time means that the reworking of the slump cannot therefore simply be attributed as being caused by aftershocks from the original earthquake.

Individual slumps up to $50 \mathrm{~cm}$ thick together with their overlying caps are cut across and repeated by thrusts that detach on coarse sand and gravel layers (with $5 \mathrm{~mm}$ pebbles) (Fig 9h). These later thrusts are interpreted as becoming emergent on the lake floor as the coarse sand and gravel forms distinct wedges at the toe of the thrust, which are overlain by aragonite-rich laminae displaying growth geometries. Later thrusts detaching on sand and gravel illustrates the stratigraphic control on thrusting, and the potential role of previously fluid-rich sediments such as gravels.

\section{Discussion}

\subsection{Does the amount of slump sheet translation sequentially vary up through a sequence?}

Mapping of the six slump sheets at Wadi Peratzim shows that older slumps (S1, S2, S3) have in general travelled further downslope towards the NE than the younger slumps (S4, S5, S6) (Fig. 4, b, 7c, Table 1). Older slumps also contain a greater detrital component that extends further downslope towards the NE. It is not possible to determine the position of the head of each slump upslope, as only the lower contractional portions are exposed. The map pattern can therefore be broadly interpreted in two different ways.

\subsubsection{Were older slump sheets larger?}

Older slumps may be larger and would therefore travel further downslope towards the NE. This could be interpreted to be a consequence of higher magnitude or more proximal earthquakes. However, older slumps would then be expected not only to be thicker but also to have thicker caps formed of material deposited from suspension after each slump event. This is indeed the case with Slumps 1 and 2 not only being thicker, but also displaying the thickest caps (Fig. 7f).

\subsubsection{Were older slump sheets triggered further downslope?}


Older slumps contain more detrital material, and the amount of detrital input then reduced with time up through the sequence. The detrital material does not therefore extend as far to the NE in younger slumps. A reduction in detrital input up through the sequence could reflect a number of variables including environmental effects such as climate (lower precipitation and fewer flood events), or changes in geomorphology of source tributaries in Wadi Ami'az. The introduction of detrital-rich sediment horizons may have facilitated failure, and these may also have progressively receded towards the SW with time. This would have resulted in each younger slump being initiated further to the SW and therefore not translating as far NE. Previous work from elsewhere (e.g. Odonne et al., 2011) has indeed shown that lateral facies changes may act as areas of relative weakness at which slope failure and slumps initiate. We suggest that detrital material may have facilitated slump translation enabling older slumps to travel further downslope. However, the position of the marginal fault bounding the Cretaceous and Lake Lisan has remained fixed, meaning that there are absolute limits as to how far headwalls of successive slumps can recede.

In summary, slump patterns at Wadi Peratzim may be interpreted as due to a) older slump sheets being larger and travelling further downslope, and b) successively younger slumps being triggered further upslope due to a smaller detrital input, thereby defining an overall retrogressive slope failure. We suggest that a combination of these two processes has operated in the case study, whereby larger slump sheets with a greater detrital component are triggered further downslope.

\subsection{Do slumps reworked by multiple seismic events display different amounts of translation?}

Each of the six slump sheets are considered to be triggered by a separate seismic event, as each slump displays erosive truncation of its upper surface (that can only form at the lake floor) and is overlain by an undeformed sequence of Lisan Formation. However, slump 5 has previously been used to illustrate the effects of a double seismic event reworking a single slump horizon (Alsop and Marco, 2011). This is based on the observation that the sedimentary cap deposited from suspension after the initial slump event, is itself then thrust and folded by a second younger event that reworks the slump 5 horizon (Fig. 9d). Slump 5 extends $150 \mathrm{~m}$ further down slope than the underlying slump 4, with this greater downslope translation interpreted to reflect this double event. Slump 5 is thicker than the two underlying slumps (S3, S4) and also doubles its spacing with the underlying slump 4, from $250 \mathrm{~mm}$ in the upslope area to more than $500 \mathrm{~mm}$ in the downslope area. (Fig 7f, Table 1). Although Alsop and Marco (2011) were unable to prove that reworking of slumps was not triggered by aftershocks, the observation in this study that later thrusts may also cut through up to $0.85 \mathrm{~m}$ of overlying aragonite-rich laminae (Fig. 9e, f) demonstrates that the second phase of slumping and thrusting occurred significantly later ( $\sim 850$ years) than the original slump. This confirms that reworking of slumps is not simply related to aftershocks from the original triggering earthquake, but to completely different seismic events. Migowski et al. (2004) discussed the 'masking' of an earthquake by a subsequent earthquake as inferred from cores elsewhere in the Dead Sea. The implication from the present outcrop based study is that 
slumps may indeed conceal more than one seismic episode, and the seismic recurrence interval calculated from counting slump intervals could therefore be overestimated.

\subsection{Do slumps maintain a constant flow direction up through a sequence of several slumps?}

Analysis of fold hinges, axial planes and fold facing data (Fig. 6) reveals that the lower slumps (S1, S2, S3) appear to have flowed towards the N and NNE, while the upper slumps (S4, S5, S6) were directed towards the NE and ENE (Table 1). There are two ways to interpret the variable slump pattern.

It is possible that there was a small change in the overall slump direction up through the sequence with older slumps (S1, S2, S3) directed towards the $\mathrm{N}$ and NNE, while younger slumps flowed more towards the NE and ENE. However, there is no obvious reason as to why such a change should occur, as the regional tectonics have not varied and the palaeoslope is therefore considered to remain relatively constant and stable (see Alsop and Marco, 2012a).

Perhaps a simpler solution relates to the general observation that fold hinge trends may fan out around the toe of slumps (e.g. Strachan and Alsop, 2006), especially where an open cast or emergent toe is developed. Fossen (2010, p. 343) notes a "divergent displacement field" around the leading toe of slumps. We suggest that the observed variation in slump fold orientations up through the sequence of six slumps simply reflects the sampling of variably orientated fold hinges around the frontal and lateral margins of broadly ellipticalshaped failures (e.g. see Fig. 1a, b).

\subsection{Does the thickness and spacing between individual slump sheets vary downslope?}

In general, individual slumps are thicker and more closely spaced relative to the underlying slump in the upslope area, and become thinner and more widely spaced when traced downslope towards the NE (Fig. 7a, b, c, d). Some slumps double their spacing to the underlying slump (e.g. slumps 4, 5, Fig. 7d) and this could reflect a number of processes:

\subsubsection{Tectonic geometry - detachments.}

Basal detachments in the contractional portions of slump sheets could cut up section in the downslope transport direction, thereby increasing the spacing to the underlying slump. However, there is no evidence of classic ramp and flat geometries along the basal detachments to slumps, and no evidence of detachments cutting and truncating underlying stratigraphic markers. In addition, the slumps are surficial, which leaves little scope for ramping upwards. Thus, the slumps lower contacts appear to be non-erosive and largely bedding parallel.

\subsubsection{Tectonic geometry - folding .}

Thicker slumps may be created due to more contraction being accommodated by folding in detrital-rich horizons towards the SW. Folding may result in more thickening to 
accommodate the same amount of contraction as a thrust. Thrusting can accommodate a greater amount of contraction for relatively limited thickening, as repeating a sequence across a thrust plane doubles its thickness, but then allows a large amount of contraction as beds simply slide over one another. Thus, the thickness of slumps would naturally reduce downslope as beds become aragonite-rich and thrusts predominate.

\subsubsection{Depositional geometry- wedges.}

Detrital units that were destined to become slump sheets may have displayed an original depositional thickness variation. The major source of detrital input is from Wadi Ami'az in the SW, and the detrital wedges may therefore be expected to thicken towards this direction and thin downslope towards the NE. Precipitation of aragonite from the upper surface waters of Lake Lisan would be relatively constant across the area, although the proportion of aragonite compared to detrital sediment would decrease towards the source of detritus in the SW.

In summary, the overall thickness and spacing pattern reflects a greater detrital input towards the SW resulting in a thicker sedimentary sequence. The greater thickness of detritals would naturally result in slumps being more widely spaced, while the increased thickness of individual slumps is considered a consequence of detrital units being more prone to folding that would significantly increase the thickness of the slumped unit.

\subsection{How does the thickness and extent of sediment caps vary above slump sheets?}

Detrital caps deposited from suspension above each slump thin downslope (Fig. 7f) and are observed to extend s beyond the toe of slumps. This suggests that the caps were locally sourced, although the preservation of breccia layers forming seismites without associated slump folds, (e.g. Agnon et al., 2006) suggests that turbid flows may extend beyond slumps.

The observation that slumps 1 and 2 tend to have thicker caps, when compared to younger slumps of similar thickness (Fig. 7f) suggests that, a) slumps 1 and 2 are larger as they extend further downslope and turbid flow has disturbed a greater amount of sediment to create the cap, or b) slumps 1 and 2 have proportionally thicker caps as they contain more detritals with which to create a pronounced capping layer. We suggest that the proportionally thicker caps above slumps 1 and 2 reflects a combination of these two processes.

\subsection{Does the amount of contraction vary towards the downslope toe of the slump?}

\subsubsection{Deformation and contraction increase downslope towards the toe of the slump}

Since the pioneering work of Farrell and Eaton (1987), it has been tacitly assumed that deformation within slump sheets will increase downslope towards the toe that is commonly interpreted to be marked by a thrust (e.g. Bradley and Hanson, 1988; Webb and Cooper, 1988). Indeed, many field based studies suggest that folds within slumps become more disaggregated (and deformed) towards the distal (toe) end of slumps (e.g. Farrell, 1984; Gawthorpe and Clemmey, 1985; Farrell and Eaton, 1987; Strachan, 2002, 2008, Strachan and Alsop, 2006; Weimer and Slatt, 2006). Increasing deformation towards the toe has been 
interpreted as due to lower layers gradually decelerating along an underlying detachment to the slump, while upper layers continue to slip thereby increasing the velocity contrast (e.g. Dasgupta, 2008 p.107). This will result in shearing and fold modification towards the leading edge of the slump. The overall view is summarised by Fossen (2010, p. 343) who notes "increasing chaos" towards both the downslope toe of the slump and the underlying detachment. However, in the case study, deformation and contraction notably decrease towards the toe (see section 4.5., Fig. $7 \mathrm{~g}$, h) suggesting an alternative model needs to be considered.

\subsubsection{Deformation and contraction increase towards the centre of the slump}

Overall, the \% contraction in each slump is lowest at the toe (10-20\%), and progressively increases upslope to $\sim 50 \%$ until the slump is no longer exposed (Fig. $7 \mathrm{~g}, \mathrm{~h}$ ). It should be noted that the actual maximum contraction values will be greater because, a) the extreme upslope areas of contraction are not exposed by the down cutting wadis, b) upslope areas are dominated by detrital input, which hinders the recognition of coherent fold and thrusts with which to estimate contraction. Alsop and Marco (2014) note that deformation increases towards areas of greatest relative acceleration or deceleration of flow. As contraction reduces downslope towards the toe, then this suggests that the greatest deformation is near the centre of the slump, close to where it initiates, and this progressively reduces outwards (Fig. 10a, b, c). Indeed this pattern corresponds to the original dislocation model of Farrell (1984) whereby basal detachments display the greatest displacement gradients towards the centre of the slump where slip initiated. In the case study, the most likely setting for the initiation of slumps is in the detrital-rich units, close to the facies transition with aragonite-rich horizons. The initiation of slumps close to facies transitions has been documented previously (e.g. Odonne et al., 2011) and may provide a major control on slump setting and architecture. In summary, \% contraction and deformation reduce downslope towards the toe of each slump system (Fig. 7g, h). Following Farrell (1984), we suggest that this simply reflects displacement gradients along the basal detachments, which are considered to be greatest where the slump initiates at the detrital-aragonite facies transition, and then to progressively diminish downslope.

\subsection{What structures mark the leading edge of slump sheets?}

Deformation is typically assumed to simply increase downslope and culminate in a toe thrust marking the downslope limit of a slump or MTD. Fossen (2010, p.343) notes "frontal imbrication" along thrusts faults marking the toe of a slump, while Garcia-Tortosa et al. (2011) record that contractional deformation typically increases downslope towards the toe of a slump system, which is marked by thrust faults. Bradley and Hanson (1988, p.311) suggest that asymmetric folds develop downslope into sheath folds, before the contractional toe of the slump is marked by a thrust. Frey-Martinez et al. (2006) divided slumps into two broad systems termed frontally emergent and frontally confined, depending on the relationships of the downslope toe with adjacent beds. 


\subsubsection{Frontally emergent slump systems}

Frontally emergent slump systems develop where large downslope translation causes the slump to ramp up and undergo unconfined flow over the sediment surface at the sea or lake floor (Frey-Martinez et al., 2006). Although this process may occur on a small scale on the floor of Lake Lisan (e.g. see section 6.2. Fig. 8d), it should be noted that these examples are developed where a reworking of the slump system by a much later event has occurred. Frontally emergent systems are therefore not considered diagnostic of the slumps at Wadi Peratzim.

\subsubsection{Frontally confined slump systems}

Frontally confined slump systems form where there is restricted downslope translation, and the slump does not overrun undeformed strata further downslope (Frey-Martinez et al., 2006). This may result in the slump being "buttressed against the downslope strata in the toe region" resulting in increasing curvature of folds in the downslope area (Frey-Martinez et al., 2005). The slumps in the case study area are considered to have relatively limited translation as their maximum downslope extent is just $2 \mathrm{~km}$ from the Cretaceous margin and there is no evidence of slumps overrunning undeformed strata. Indeed, each slump is observed to pass laterally downslope into undeformed beds (Fig. 8e-h). However, the tip of each slump is not marked by a discrete thrust or imbricate thrust complex, and frontally confined systems are therefore not thought to be representative of slumping in the current study.

\subsubsection{Open-ended slump systems}

Several studies have discussed the possibility of compression in the downslope toe of a slump being accommodated via lateral compaction of fine grained sediments, thereby leaving no discernible structures and 'open-ended' toes (e.g. Crans et al., 1980; Mandl and Crans, 1981; Garfunkel, 1984, see also Martinsen, 1994, p.147; Morgan and Karig, 1995; Van der Merwe et al., 2011). The downslope strain is effectively dispersed via porosity reduction rather than formation of distinct thrusts (e.g. Mandl and Crans, 1981; Martinsen, 1994, p.155). Mandle and Crans (1981, p.50) suggest that "the rate of sliding will be controlled by the rate of slopeparallel compaction" and the process is therefore 'slow'. They also suggest (Mandl and Crans, 1981, p 51) that "slip plane formation is preceded by considerable continuous deformation" with simple shear becoming concentrated into basal slip planes. Analysis of drill cores through thrusted sediments of the Nankai accretionary prism led Morgan and Karig (1995) to suggest that $68 \%$ of total shortening may be attributed to "diffuse internal strain" rather than discrete thrusts.

Within the case study, upright folds are thought to be the $1^{\text {st }}$ contractional structures to form as the downslope slumping initiates (Alsop and Marco, 2011) and are preserved in the aragonite-rich facies towards the toe of each slump sheet (Stage 1, Fig. 10a). As the slump starts to translate, the early upright folds are sheared over to create a downslope asymmetry or vergence (Stage 2, Fig. 10b). Continued later translation of the slump sheet results in a failure of the fold limbs and downslope verging thrusts (Stage 3, Fig. 10c). These relationships suggest that folds initially form and then later (thrust) deformation propagates 
through these folds. Similar sequences of deformation have been interpreted in orogenic belts (e.g. Ortner et al. 2015) and also generated in analogue models of fold and thrust systems (e.g. Cosgrove, 2015, fig 9). Thus, the general spatial pattern indicates an overall downslopepropagating sequence of deformation, with the oldest and most evolved (Stage 3) structures preserved closer to the point of slump initiation (Fig. 10c), while the youngest and least evolved upright, weak folds, which are unaffected by later thrusting, are still preserved at the extreme toes of slumps (Fig. 10c).

Within the slumps at Wadi Peratzim, the lack of reworking by late stage thrusts towards the toe suggests that deformation related to cessation of each slump sheet is limited (see Farrell, 1984; Alsop and Marco, 2011). This absence of 'cessational strain' is perhaps due to gentle displacement gradient into a 'soft' open-ended toe, with a diffuse boundary at the toe leading to distributed strain (Fig. 10). A soft open-ended toe may develop due to a) the shallow, surficial nature of the thrusts that affect packages of Lisan sediment $<1 \mathrm{~m}$ thick, b) laterally migrating fluids along detrital horizons (e.g. Cosgrove, 2015), c) displacement gradients (and hence deformation) being greatest where facies changes from detritals to aragonite have developed. Facies change controls displacement gradients and hence deformation profiles. Rates of downslope movement may have been relatively rapid over a short period, as slumping was completed before sediment caps were deposited from suspension in a matter of hours or days (Alsop and Marco, 2012b). We suggest that upright folding at the open toe (Fig. 10) was able to keep pace and accommodate slump translation as the total amounts of downslope movement at the toe may have been relatively small.

In summary, the observation that thrusts die out downslope into upright folds indicates that the leading edge of the translating deformation cell is not a distinct tip line thrust, but rather a soft diffuse open-toed boundary marked by lateral shortening and compaction within layers (Fig. 10). If similar processes occur at the seismic scale, then restoring thrusts and faults on seismics will not equate to all shortening. This has been recognised by de Vera et al. (2010) and Butler and Paton (2010) who calculate that up to $40 \%$ more contraction is required to balance the extensional components of slumps imaged from offshore seismic sections. This 'missing' contraction is suggested to be accommodated by sub-seismic scale lateral compaction of the sediments (e.g. Morgan and Karig, 1995).

\subsection{Does lithological variation control structural style within slump sheets?}

The control of lateral sedimentary facies changes on slumping in MTD's has been previously invoked from large-scale outcrop studies (e.g. Odonne et al., 2011 and references therein) as well as from studies of seismic sections such as Frey-Martinez et al. (2005, p.104) who note the "deep rooting of basal shear surface within the underlying strata probably because of an abrupt lithological variation". It has been suggested that silty layers may preferentially undergo soft sediment deformation when compared to adjacent sand-rich horizons in the Himalayas (e.g. Mugnier et al., 2011). On a smaller scale, Garcia-Tortosa et al. (2011) note that slumps detach on a clay-rich bed containing sepiolite that is considered to have liquidised due to the thixotropic behaviour of the clay minerals. 
Within the case study, the stacked system of six slumps follows a set sequence controlled by sedimentary facies with the source of each younger slump progressively migrating towards the SW. This results in older, detrital-rich (folded) slumps being vertically overlain by younger aragonite-rich (thrusted) slumps, i.e. slumps typically get thinner and more aragonite-rich up any vertical wadi wall (Fig. 5).

\subsubsection{Does lithology control structural character?}

Slumps 1, 2, and 3 are sampled more in their upslope detrital-rich facies and display a higher

$\%$ of contraction linked to greater deformation (Fig. $7 \mathrm{~g}, \mathrm{~h}$ ). This results in greater fold rotation and a more chaotic character in these sediments (see Alsop and Marco, 2013). Conversely, data from slumps 4, 5 and 6 are collected more in the aragonite-rich facies and show a more coherent pattern with less scatter of fold hinges (Fig. 6d, e, f). The general increase in upslope contraction coincides with an increase in thickness of individual slump sheets as they are traced upslope (see section 7.4). A contraction of 50\% cannot account for the more than tripling of slump thickness when traced upslope. Indeed, some slumps display an increase in thickness by a factor of $>10$ (e.g. slumps 4, 5, Fig. 7a-d). This marked increase in slump thickness must be achieved via additional factors that may include a) deformation of an original sedimentary wedge and/or b) a proportion of shortening and thickening being taken up by layer parallel compaction that would not produce distinct structures. This could remain largely undetected, especially in detrital-rich sediments with limited markers (e.g. slump 3).

\subsubsection{Does lithology control the position of basal detachments?}

Major extensional faults associated with the head of the slump sheets are not observed in this case study. Although this may be a consequence of limited upslope exposure, extension may also be partially hidden by a) bedding parallel detachments, b) ductile thinning and vertical attenuation resulting in horizontal thinning of units, c) extensional shear fractures in aragonite-rich units, as described by Alsop and Marco (2014) (Figs. 8a, b). These processes leave few discernible structures, and such areas of relatively broad diffuse strain would not be detectable on seismic sections across larger scale MTD's.

We consider basal detachments of slump systems to be focussed immediately below thick, detrital wedges deposited from wadi floods (Fig. 11a, b). Deformation is concentrated at the base of these detrital horizons, which pass laterally into more aragonite-rich beds (Fig. 11a, b). Detrital-rich layers are also observed to act as internal detachments within the slump sheets, and locally compartmentalise deformation through the slumped mass itself (see Alsop and Marco, 2014) (Fig. 11b). Structures also detach on sand and gravels where present, perhaps because they were saturated and relatively weak at the time of deformation (e.g. Fig. 9h). It should be noted that the Lisan Formation is generally assumed to have been water saturated at the time of deformation, while the present water content is still $25 \%$ (e.g. Arkin and Michaeli, 1986). Although complete de-watering has not occurred, slumps contain structures such as upright 'mushroom' shaped folds that have previously been considered to relate to de-watering (e.g. Alsop and Marco, 2012, see their fig. 7f). In addition, numerous 
clastic dykes result in de-watering, and contain transported (fluidised) sediment sourced from within slumps of the Lisan Formation.

In summary, the alluvial fan and detrital-rich sediments towards the mouth of Wadi Ami' az pass laterally towards the NE into aragonite-rich facies marking background precipitation in Lake Lisan (Fig. 11a). This wedge-shaped stratigraphic template associated with variable detrital input controls the mechanical stratigraphy and behaviour of slumps within the Lisan Formation. (Fig. 11b). A greater input of detritals towards the mouth of the wadi in the west typically results in slope failure close to the lateral facies transition (Fig. 11b). Detrital-rich units accommodate extension by ductile attenuation and detachments, while contraction is typically associated with folding. Conversely, aragonite-rich units precipitated towards the basin encourage a greater component of thrusting to develop (Fig. $11 b)$.

\subsection{What factors control the timing and frequency of slumps?}

Slumps within the Lisan Formation are widely established as being triggered by seismicity along the Dead Sea Faults (e.g. Marco et al., 1996; Begin et al., 2005). This work has demonstrated that each slump may be traced upslope and detaches below detrital-rich units sourced from nearby wadi flash flood events. Clearly, there is no obvious or inherent linkage between the timing of climatically triggered wadi floods and major earthquakes, so the question becomes one of how seismicity and floods may coincide.

\subsubsection{Could slumps utilise older detrital units?}

If slumps formed below the sediment surface, then there is no necessity for wadi floods and the major seismic event to coincide, as slumping could simply utilise a much older detrital unit which had become buried below the sediment surface. However, slumps clearly interact with sedimentary processes including erosion and truncation of the top of the slump sheet, followed by deposition of the sedimentary cap that infills local bathymetry and deposits aragonite clasts on the leeside of obstacles (Alsop and Marco, 2012b). The maximum undeformed stratigraphic thickness of sediments that undergo slumping is typically $<1 \mathrm{~m}$, indicating that detachments along the base of slump sheets developed at depths of $<1 \mathrm{~m}$ below the sediment-water interface (lake floor). The position of the detachment may therefore have been controlled by the depth to detrital-rich horizons, with the stratigraphic sequence above the detachment then thickened and repeated in the downslope contractional toe.

\subsubsection{Is deformation amplified within the basin?}

It has been calculated by Jacoby et al. (2015) that the overall location of the Peratzim area between the Cretaceous margin to the west and the Sedom salt wall to the east (Fig. 2d, Alsop et al., 2015; 2016) may have amplified seismic waves in this setting. It has also been suggested previously (e.g. Leeder, 1987; Obermeier and Pond, 1999; Wheeler, 2002) that earthquakes must reach a threshold of magnitude 5 before soft-sediment deformation and slumping will be triggered. We suggest that amplification of seismic waves could lead to 
more slumping in the case study area, and may result in slumps being triggered by earthquakes of a lower magnitude than normal.

\subsubsection{Could slumps initiate in detrital-rich horizons without major seismicity?}

It may be that relatively low level 'background' seismicity is frequent enough to trigger slumps below detritals whenever they are deposited. It does not require a 1 to 1 correlation with major seismic events to develop major slumps, especially given the potential for seismic wave amplification noted above. Elsewhere in the basin where there are less detritals (e.g. Masada, Fig. 2c) then fewer slumps appear to be developed, although it is unclear as to what effect (if any) seismic wave amplification may have in these other settings. Thus, we suggest in the case study that there is enough background seismicity to trigger slumps whenever the sediment cover above a detrital unit has reached a thickness of approximately $1 \mathrm{~m}$. Given the detrital horizons, slumps may not require a magnitude 5 earthquake to trigger them, thereby hindering their use in estimating seismic recurrence of major earthquakes.

\subsubsection{Frequency of slumps}

Each slump sheet at Wadi Peratzim effects an undeformed stratigraphic thickness of $<1 \mathrm{~m}$ (i.e. the basal detachment was shallow). As the rate of deposition of the Lisan Formation has been calculated to be $\sim 1 \mathrm{~mm}$ per year (Prasad et al., 2009), then the $1 \mathrm{~m}$ thick sequence will take $\sim 1$ ka to be deposited. Thus, the earthquakes that trigger slumping need to occur within $1 \mathrm{ka}$ of the wadi flood event that introduced detritals below which the slumps detach (and perhaps considerably less as rates of deposition will be greater with increased detrital input). The undeformed beds between slumps would be deposited after lower slump events, but below the detrital horizon upon which the overlying slump detaches. These inter-slump beds provide the spacing between slumps and are $<1 \mathrm{~m}$ (and typically $<0.5 \mathrm{~m}$ for slumps $4,5,6$, Fig. 7d). Thus, based on the average thickness of slumped beds and intervening undeformed horizons, and assuming a depositional rate of $\sim 1 \mathrm{~mm}$ per year, a seismic event large enough to trigger slumping occurred at intervals of $1.5-2 \mathrm{ka}$. Some earthquakes may however occur more frequently if slump sheets are reactivated by a second seismic event. Major earthquakes $(>$ M5.5) are estimated to occur every $1.6 \mathrm{ka}$ in the Lisan Formation in the Peratzim area (Marco et al., 1996). However, it is unlikely that such (>M5) earthquakes would correlate so well with earlier major flood events. It is therefore perhaps more likely that lower magnitude but more frequent 'background' seismicity is capable of generating slumps. If we extrapolate the observations from the Peratzim area to the scale of the basin, then the amount and frequency of slumping associated with MTD's around the basin is partially dependent on the introduction of detritals from wadi flood events. Environmental considerations such as the surrounding palaeogeography, distribution of wadis with output into the lake, and frequency of wadi flood events reflecting climate will therefore all influence temporal and spatial patterns of slumping in to the basin.

\section{Conclusions}


Six individual slump sheets are identified at Wadi Peratzim and traced for up to $1 \mathrm{~km}$ across strike towards the NE and the depocentre of the Dead Sea Basin. All six slump sheets show a systematic change in sedimentary facies from detrital-rich in the SW to more aragonite-rich in the NE. The detritus is predominantly sourced from Wadi Ami'az which erodes through the Cretaceous carbonates and clays at the basin margin $1.5 \mathrm{~km}$ further SW, while the aragonite-rich facies represents summer evaporation in the hyper saline Lake Lisan. Migrating slump systems typically result in detrital-rich older slumps being vertically overlain by younger aragonite-rich slumps, i.e. stacked slump systems get thinner and more aragonite-rich up any vertical section. This stratigraphic template provides broad controls on the structural development of slump sheets, and permits the following general conclusions to be drawn.

\subsection{Sequential variation in extent of slump sheets through a sequence, with lower slumps} extending furthest downslope and containing a greater component of detrital material. The stacked system of slumps follows a set sequence with the oldest slump sheets (S1, S2, S3) travelling furthest NE, while younger slumps (S4, S5, S6) do not translate as far downslope. It is likely that lower slumps were larger as they display thicker capping units (suggesting a greater volume of sediment was thrown into suspension by turbid flow), and also initiated further downslope due to a greater input of detritals that extended further NE.

\subsection{Slumps reworked by multiple seismic events are thicker and display greater amounts of translation.}

Slumps that have previously been shown to be created by a double seismic event are generally thicker, and marked by a greater downslope translation compared to the immediately overlying and underlying slumps. Thus, some slumps may conceal more than one seismic event, meaning that simple counting of slumped intervals may significantly underestimate seismic recurrence intervals.

\subsection{Slumps display variable fold orientations up through a sequence}

Variable slump fold orientations through a sequence may reflect temporal or spatial changes in flow. In the present case study, we suggest that the observed variation in slump fold orientations up through the sequence of six slumps simply reflects the sampling of variably orientated fold hinges around the frontal and lateral margins of broadly elliptical-shaped failures.

8.4. The thickness of individual slump sheets reduces downslope, while the spacing between adjacent slumps increases.

Rapid deposition of detritals associated with wadi floods may cause an overall taper to the slump sheet geometry. The upslope thickening of each slump sheet therefore reflects a 
a)

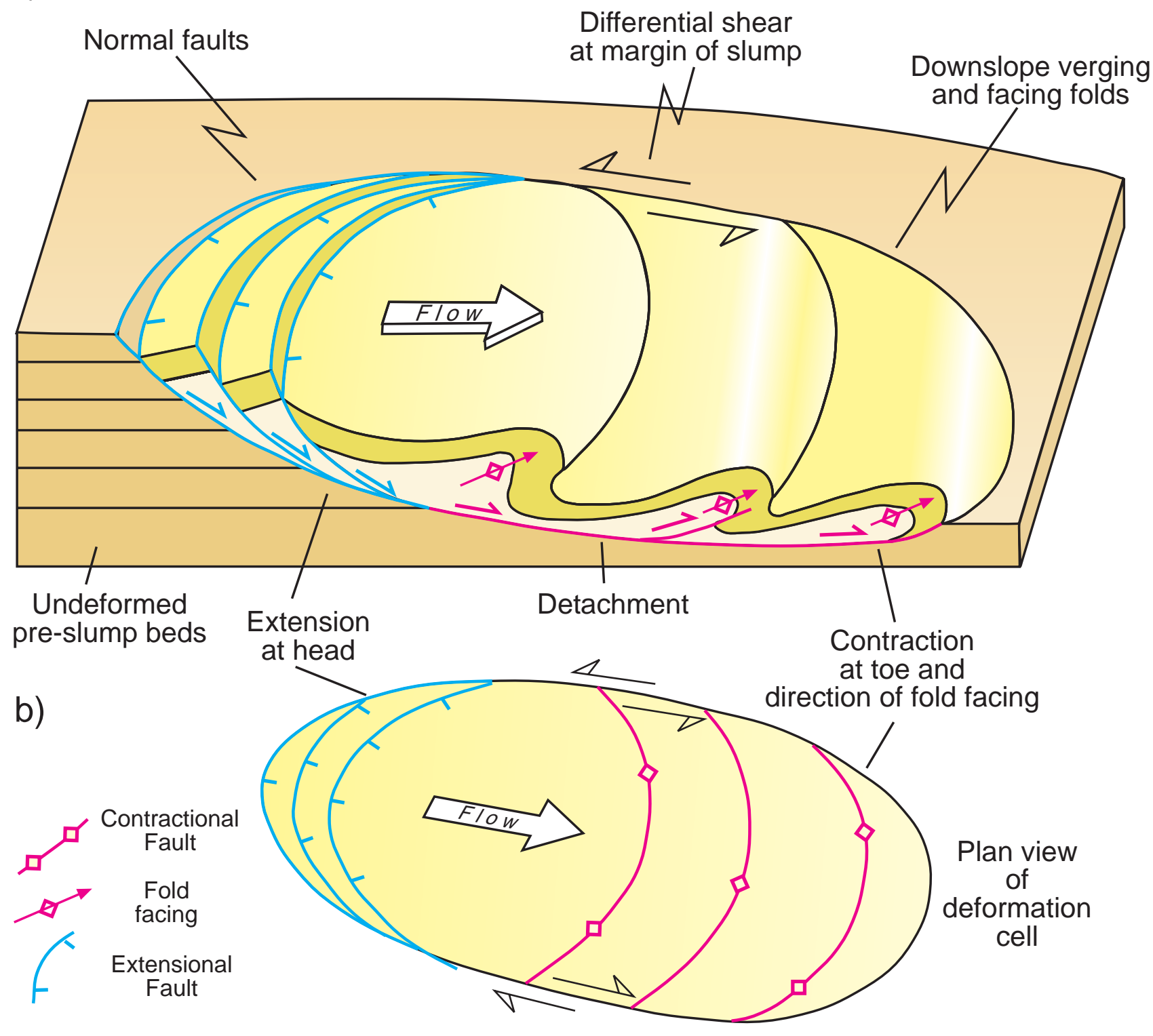



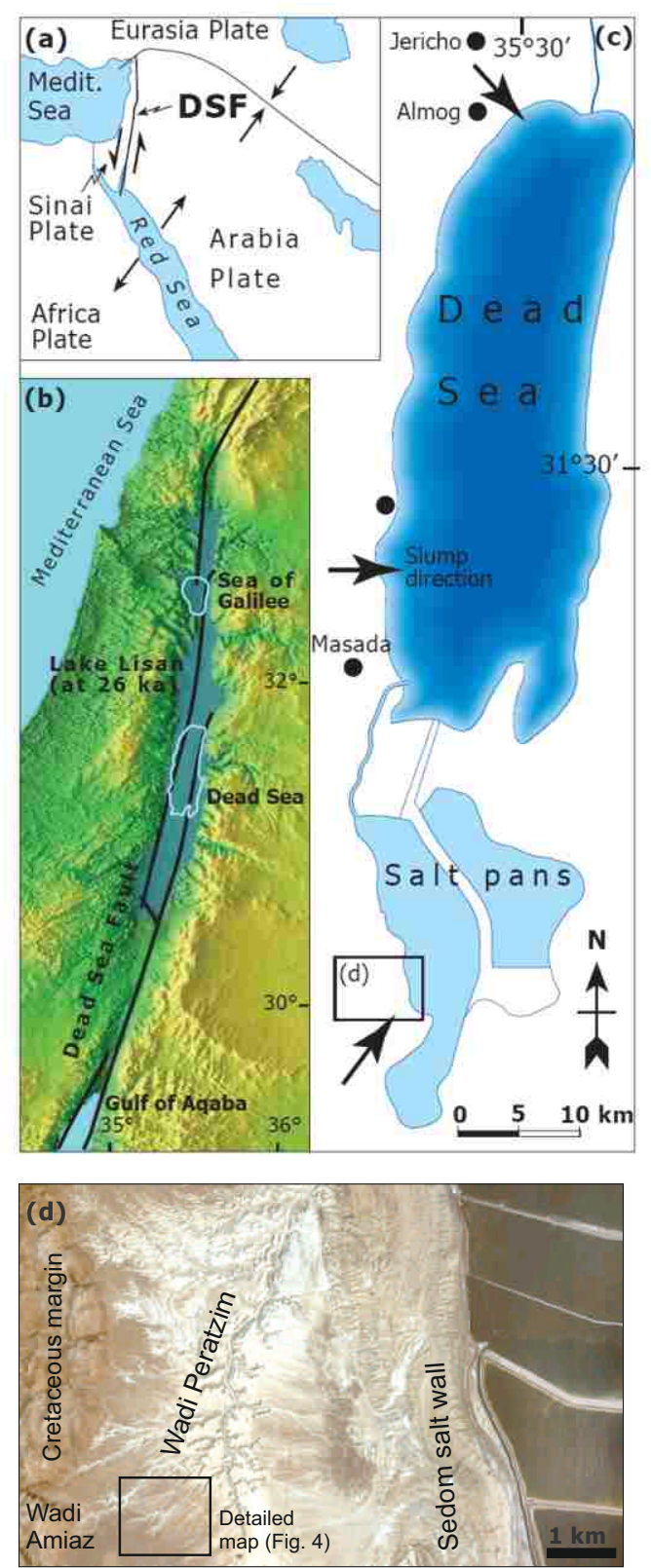
Fig 3
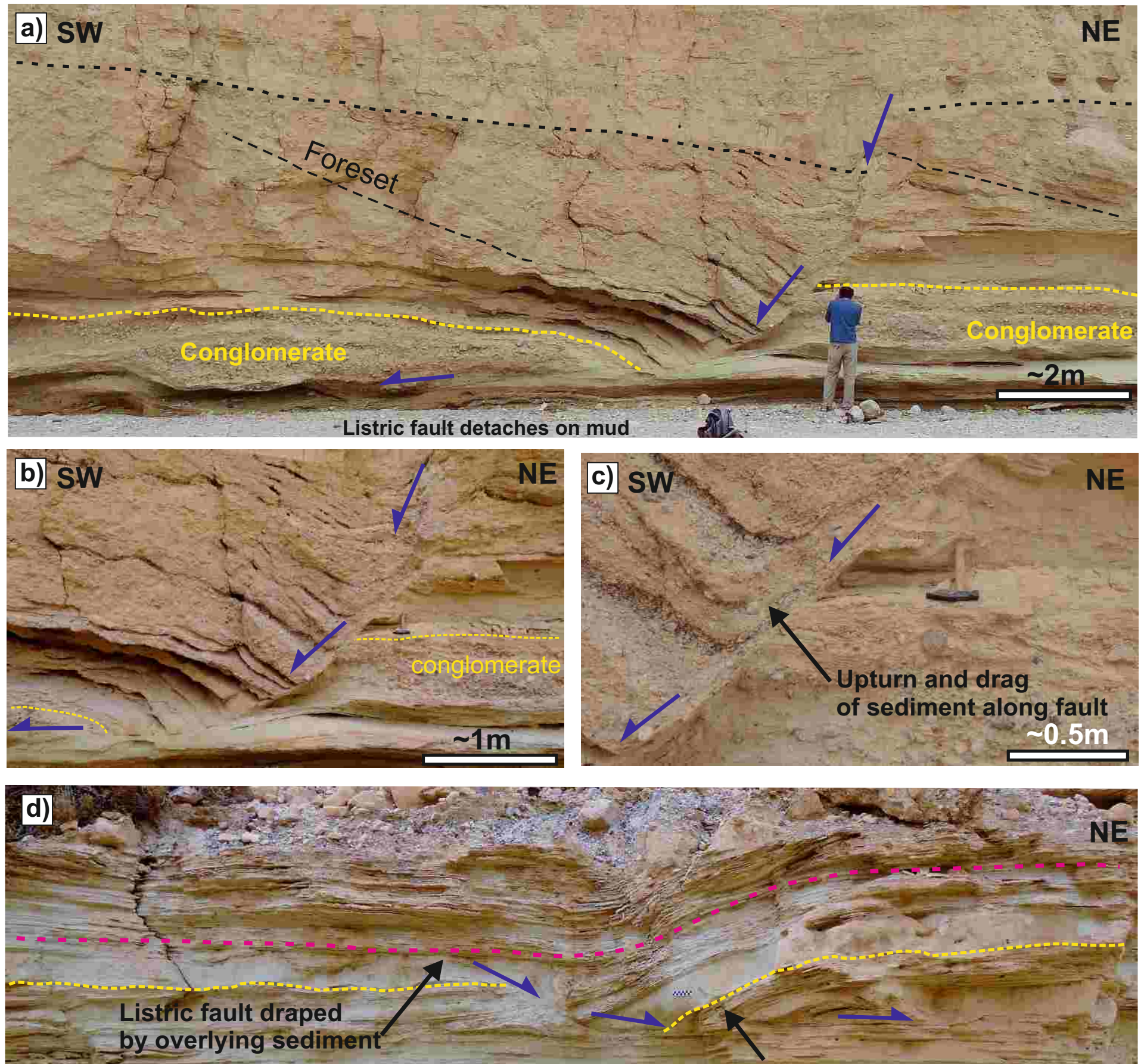

Rollover anticline in

hangingwall of extensional fault
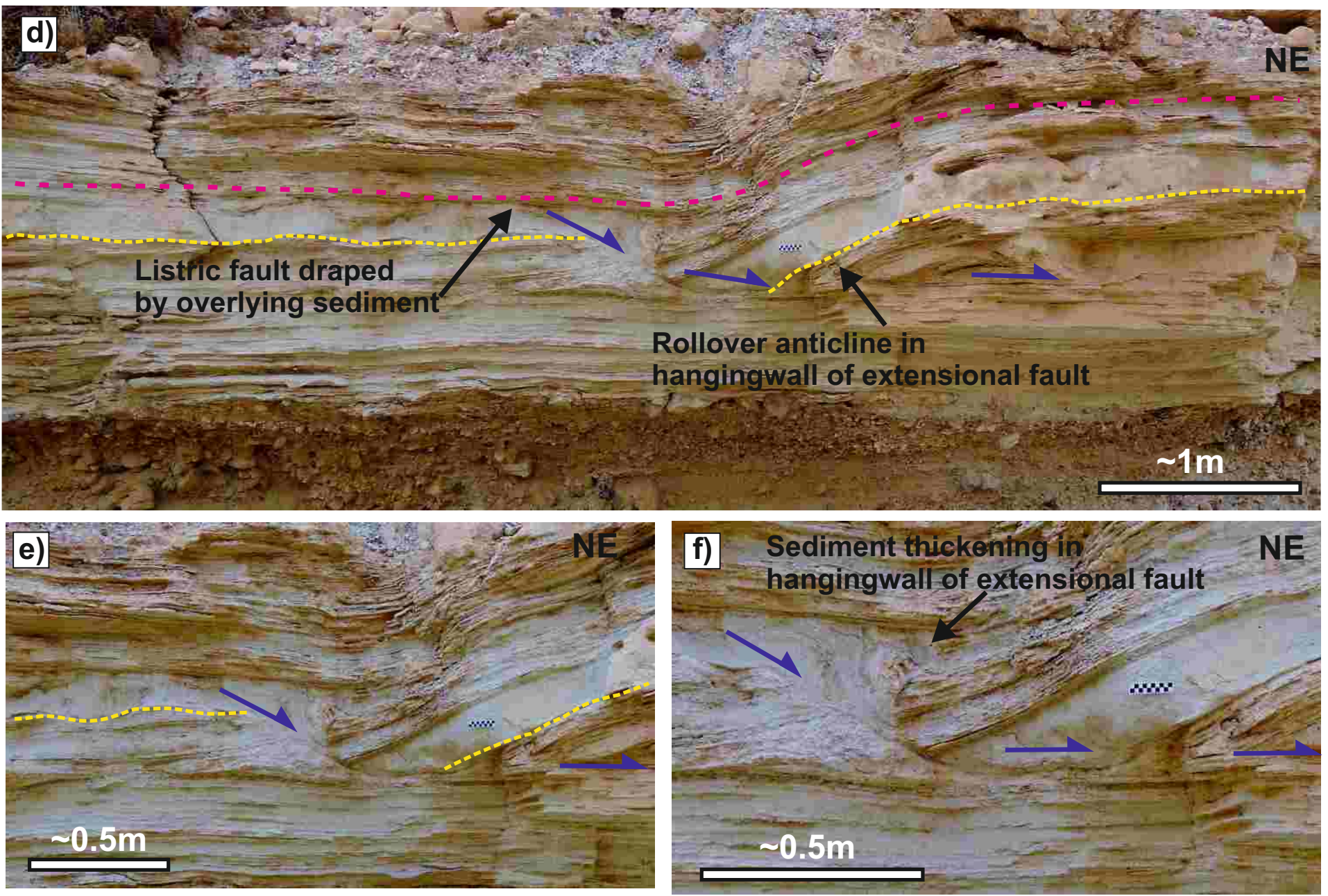


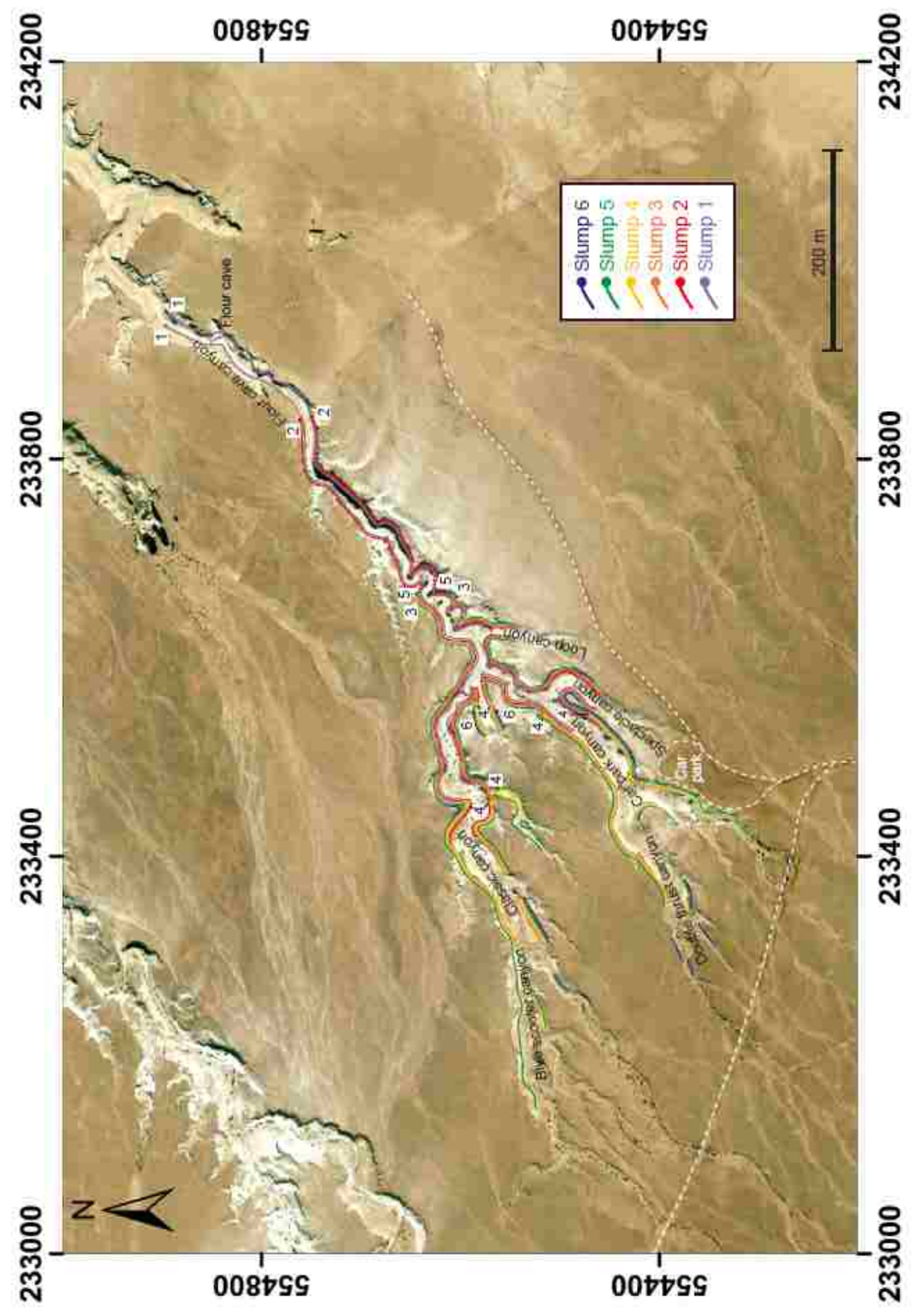




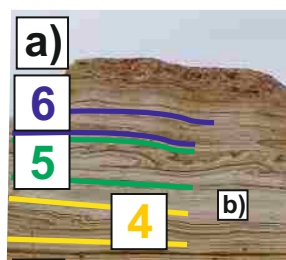

3

Slump 4 dies out into undeformed beds

$\sim 2 \mathrm{~m}$
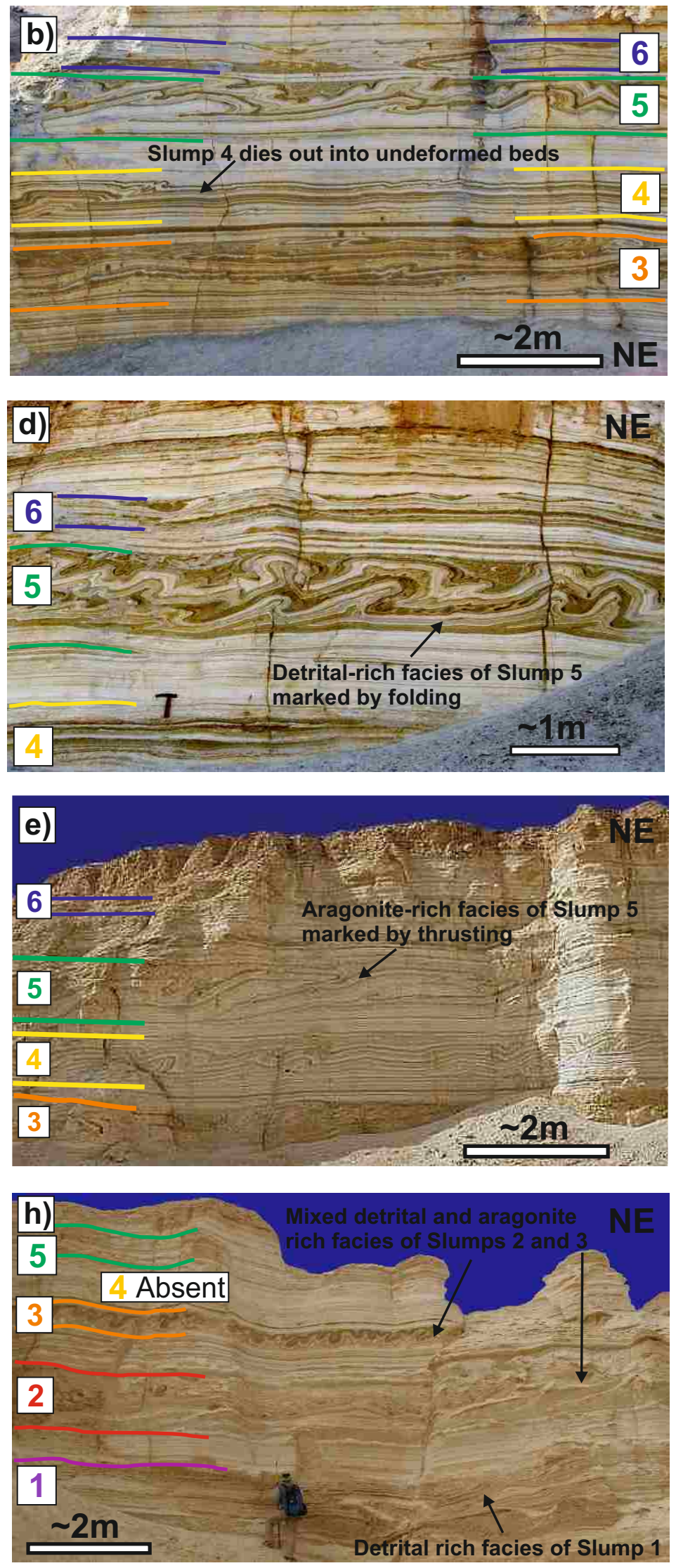
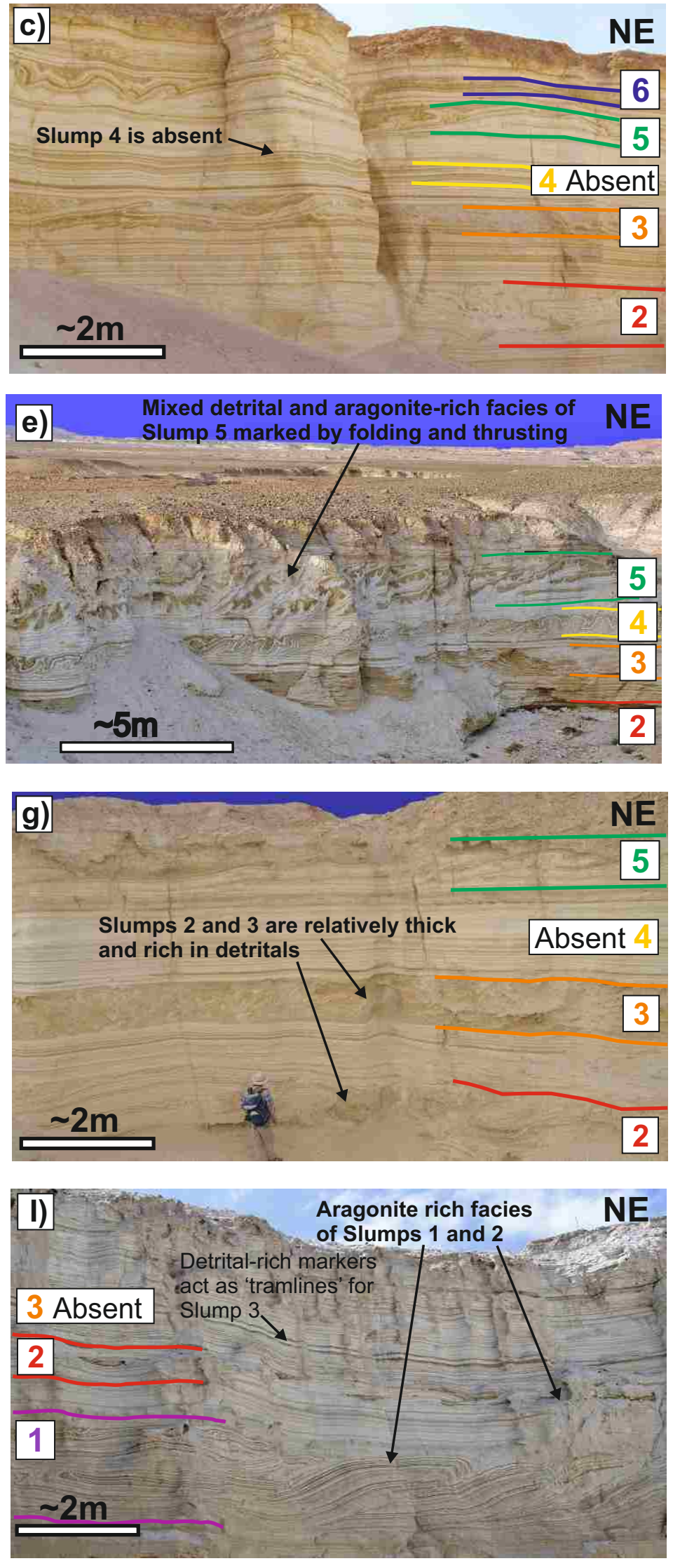

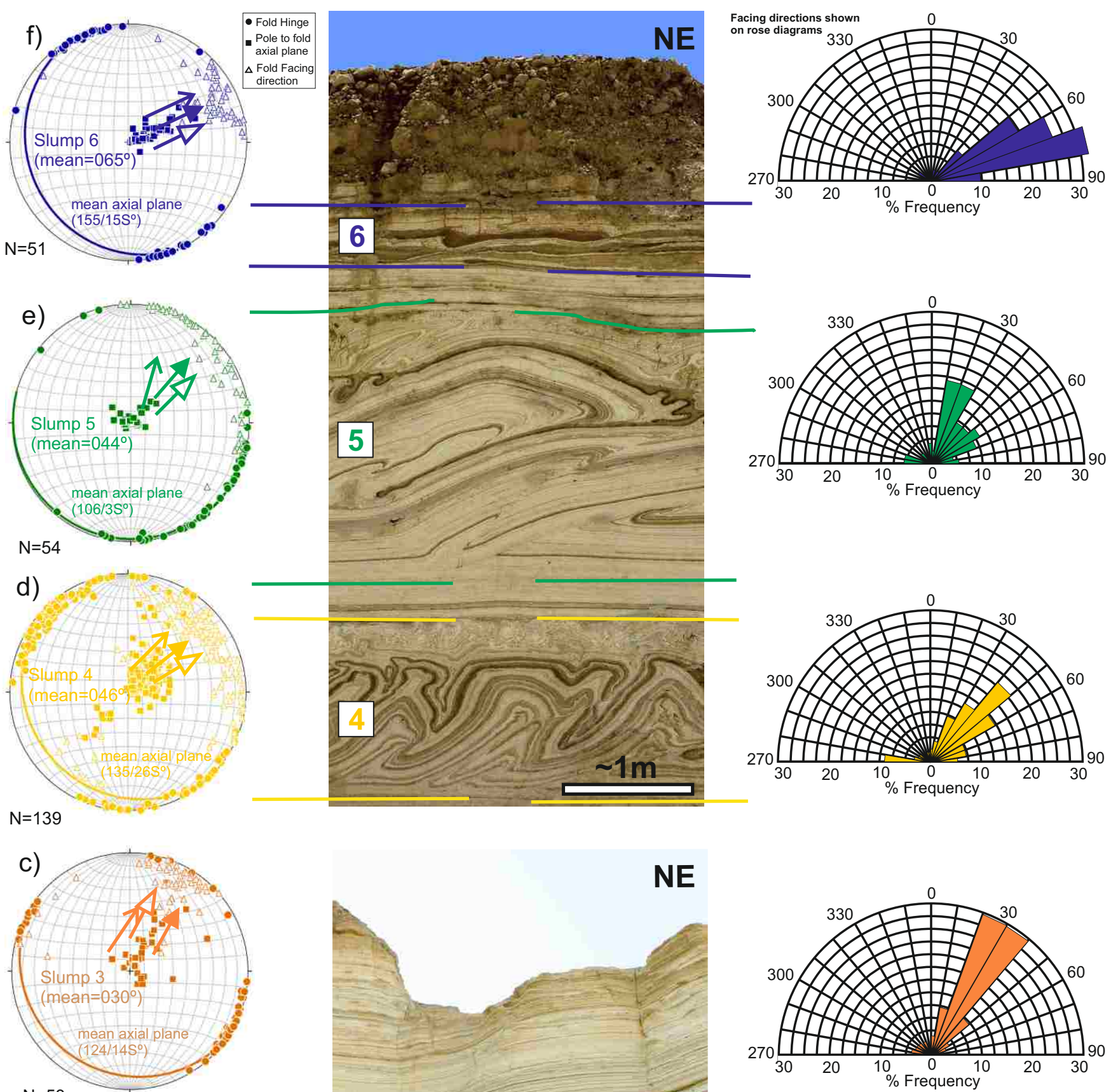

$N=53$

b)
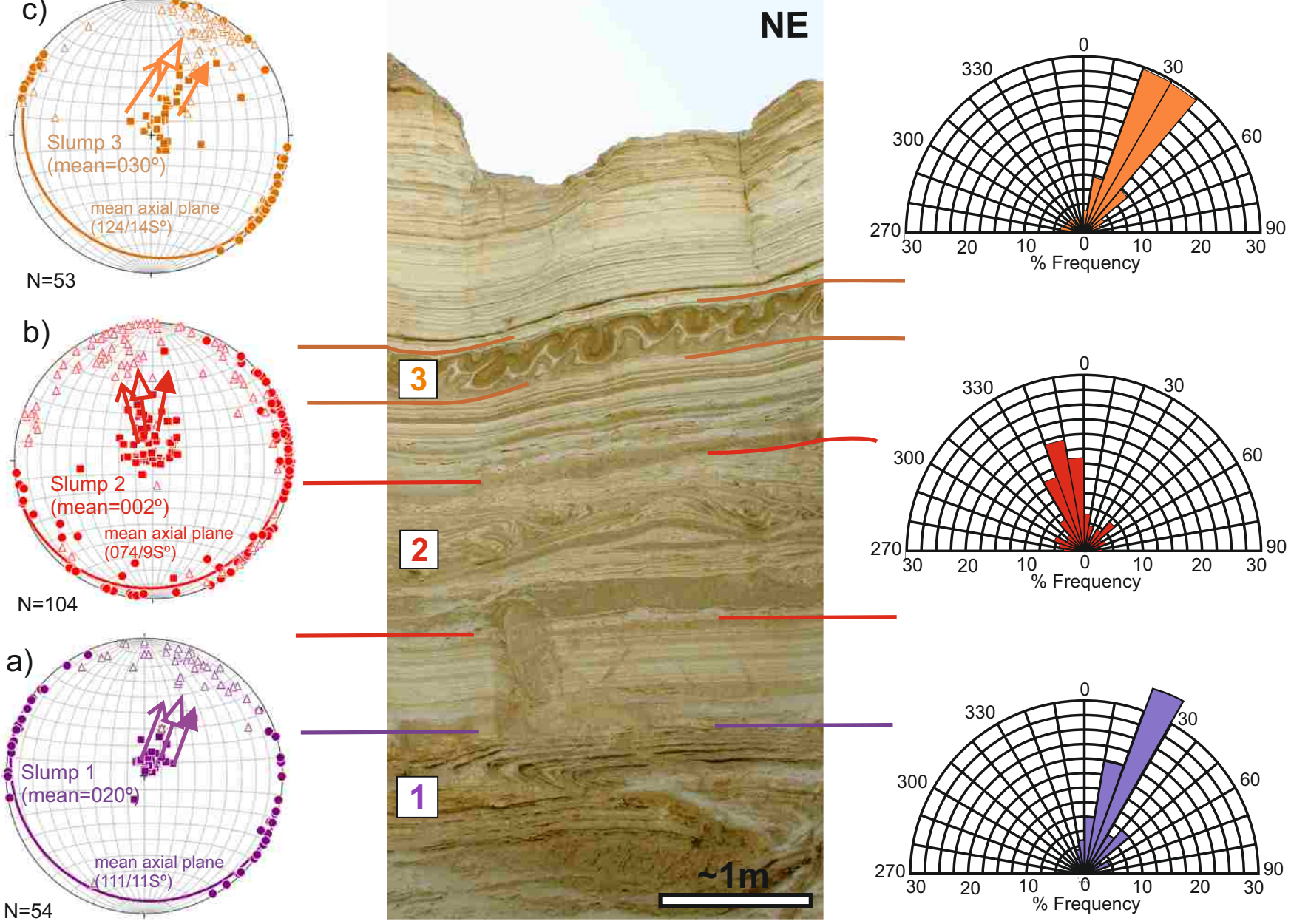

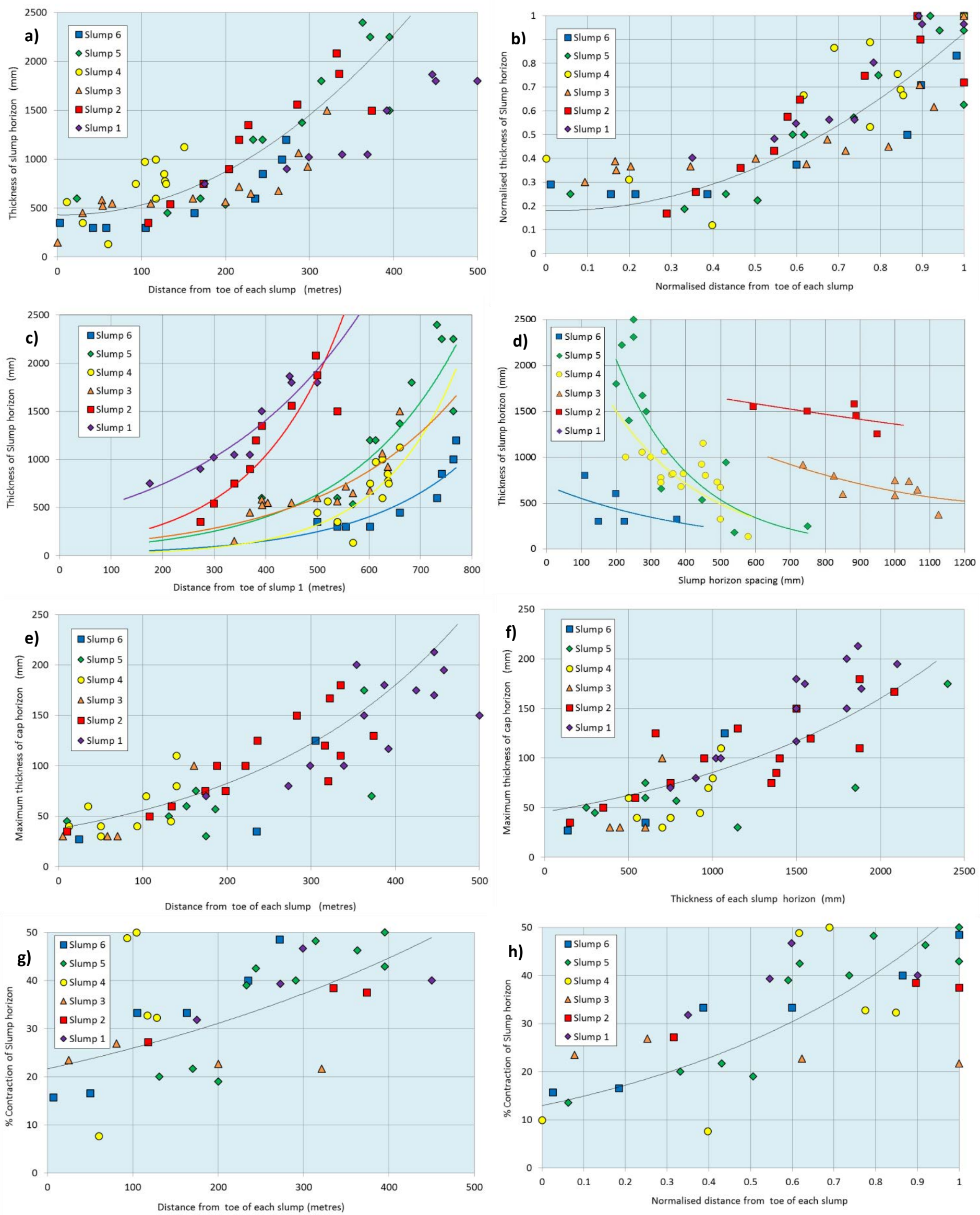

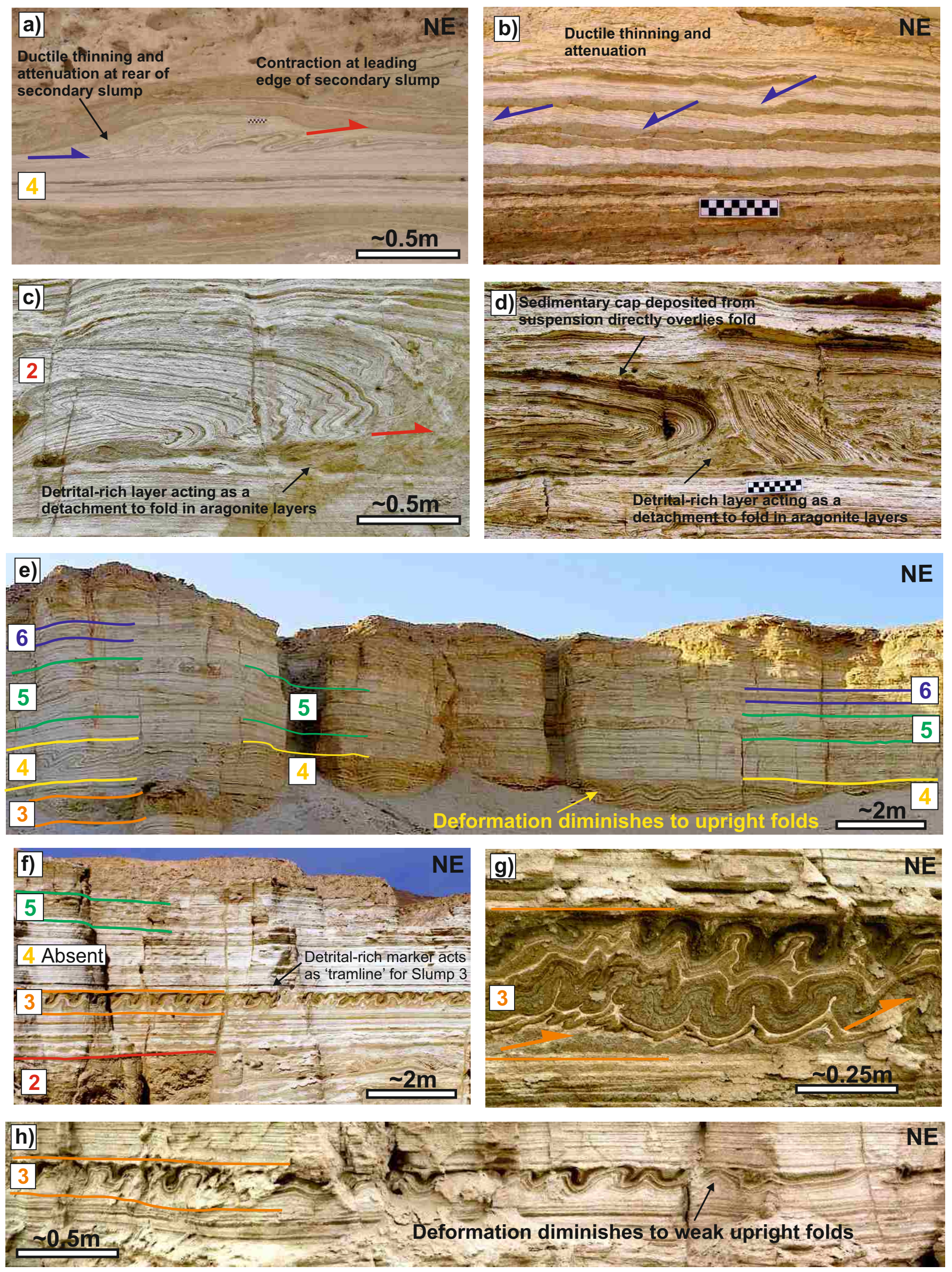

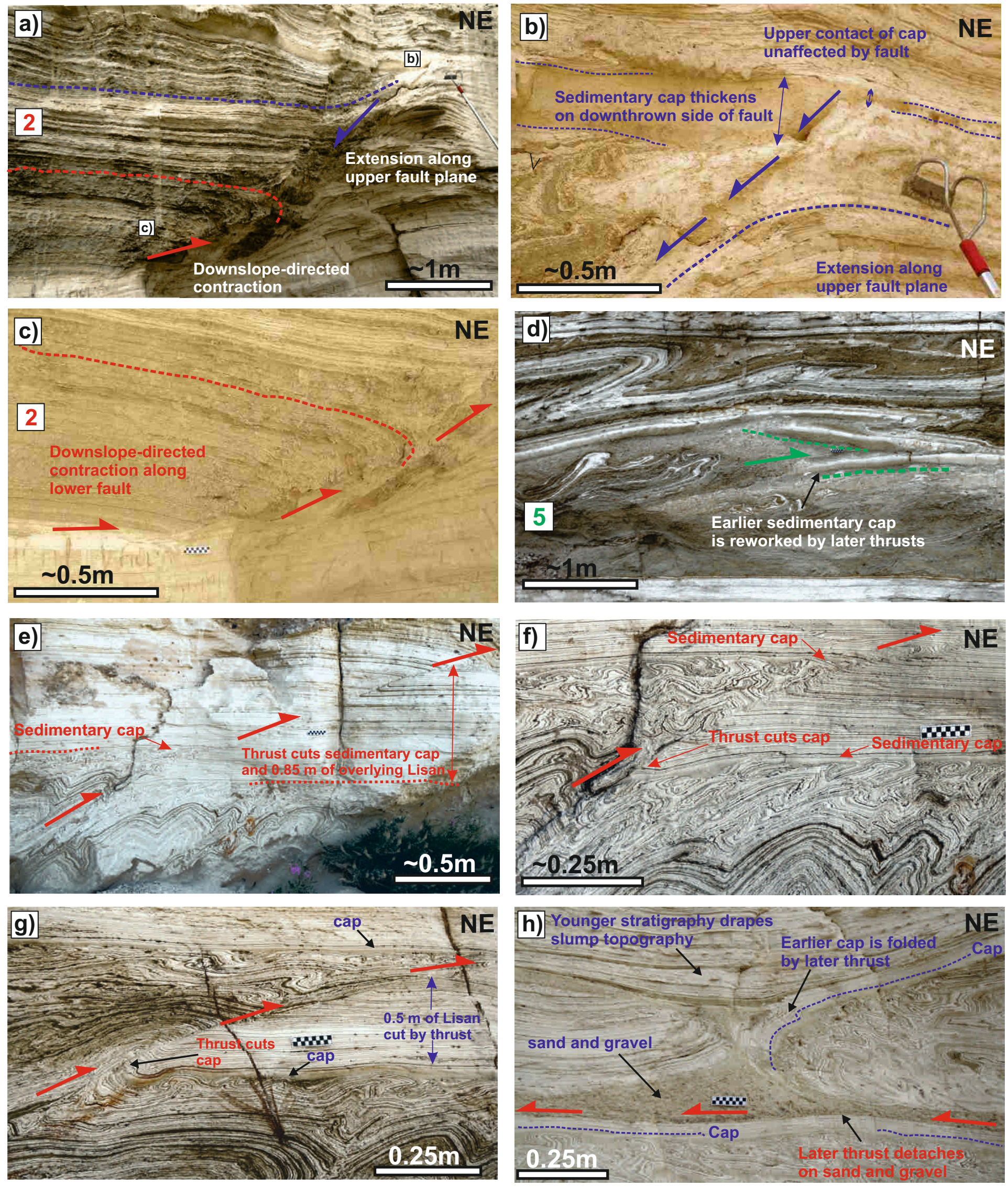

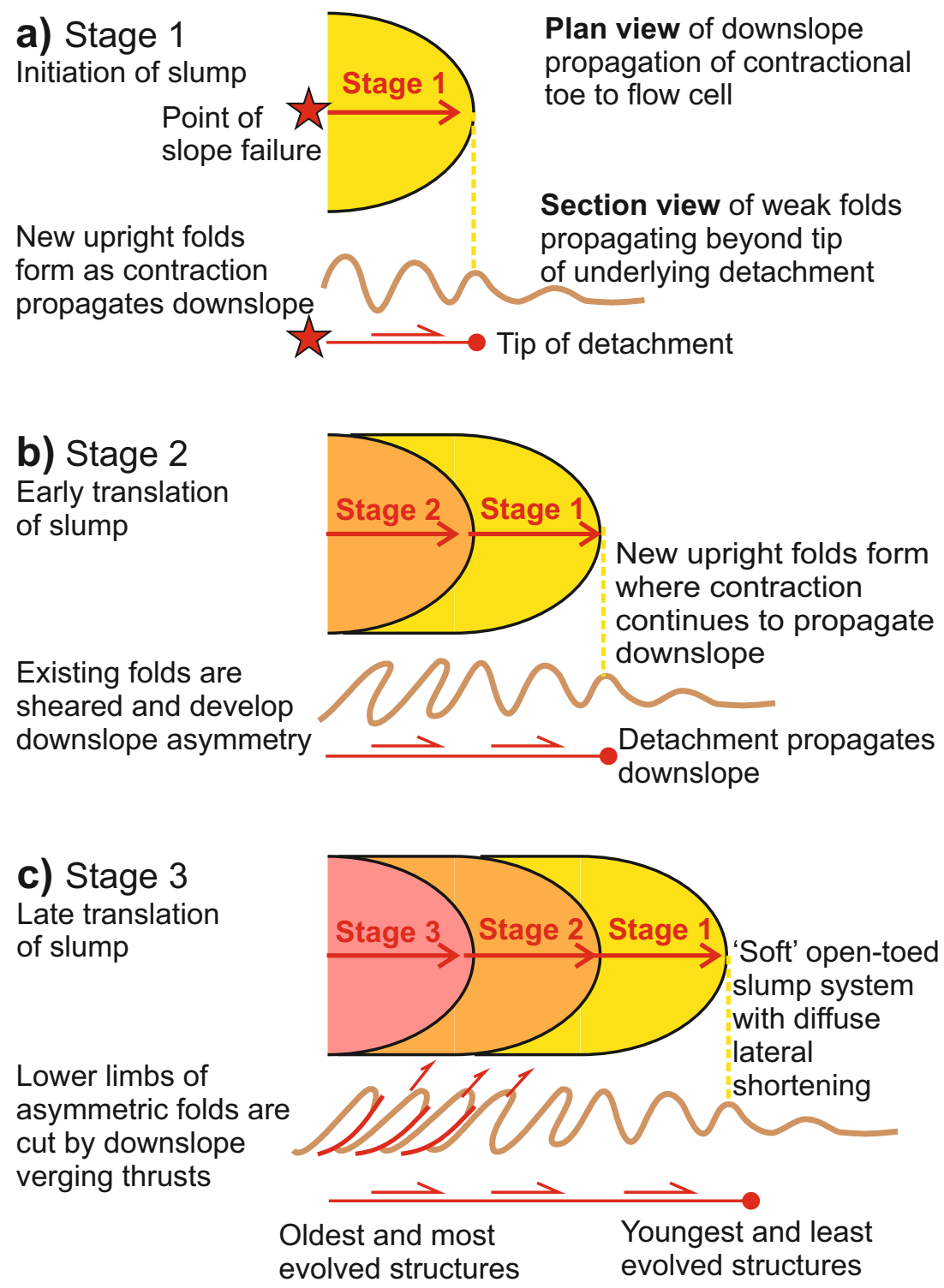
a)

Wadi outlet Thicker detrital-rich units towards wadi outlet

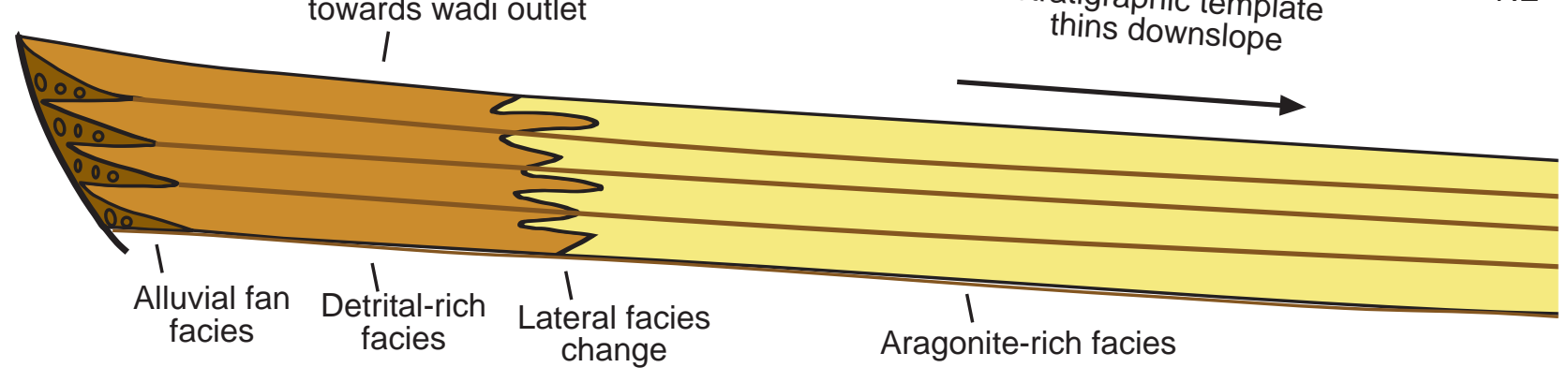

b) Head

Ductile attenuation and bedding-parallel detachments in detrital-rich units
Folding in detrital-rich units

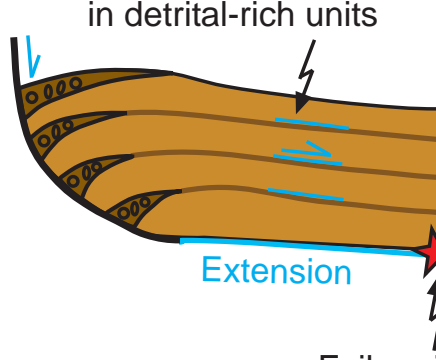

Failure initiates in water-rich detrital units
Wedge-shaped

stratigraphic template change

\section{Open-toed slump}

Thrust belt in aragonite-rich facies

Deformation diminishes NE downslope

Contraction

Tip of detachment 